\title{
Functional analysis of oxidative burst in sugarcane smut-resistant and -susceptible genotypes
}

\author{
Leila P. Peters ${ }^{1}$ - Giselle Carvalho ${ }^{1,3} \cdot$ Milca B. Vilhena ${ }^{1} \cdot$ Silvana Creste $^{2}$ • \\ Ricardo A. Azevedo ${ }^{1}$ - Claudia B. Monteiro-Vitorello ${ }^{1}$
}

Received: 7 August 2016/ Accepted: 13 December 2016/Published online: 21 December 2016

(C) Springer-Verlag Berlin Heidelberg 2016

\begin{abstract}
Main Conclusion Smut pathogen induced an early modulation of the production and scavenging of reactive oxygen species during defence responses in resistant sugarcane that coincided with the developmental stages of fungal growth.

Sporisorium scitamineum is the causal agent of sugarcane smut disease. In this study, we characterized sugarcane reactive oxygen species (ROS) metabolism in response to the pathogen in smut-resistant and -susceptible genotypes. Sporisorium scitamineum teliospore germination and appressorium formation coincided with $\mathrm{H}_{2} \mathrm{O}_{2}$ accumulation in resistant plants. The superoxide dismutase (SOD) activity was not responsive in any of the genotypes; however, a higher number of isoenzymes were detected in resistant plants. In addition, related to resistance were lipid peroxidation, a decrease in catalase (CAT), and an increase in glutathione
\end{abstract}

G. Carvalho and M. B. Vilhena contributed equally to this manuscript.

Electronic supplementary material The online version of this article (doi:10.1007/s00425-016-2642-z) contains supplementary material, which is available to authorized users.

Claudia B. Monteiro-Vitorello

cbmontei@usp.br

1 Escola Superior de Agricultura "Luiz de Queiroz" (ESALQ), Universidade de São Paulo, Av. Pádua Dias 11, PO BOX 83, Piracicaba, SP 13400-970, Brazil

2 Centro Avançado de Pesquisa Tecnológica do Agronegócio de Cana-IAC/APTA, Rod. Antonio Duarte Nogueira, Km 321, Ribeirão Preto, SP, Brazil

3 Current address: Universidade Estadual Paulista Júlio de Mesquita Filho (UNESP), Ilha Solteira, SP 15385-000, Brazil
S-transferase (GST) activities and an earlier transcript accumulation of ROS marker genes (CAT3, CATA, CATB, GST31, GSTt3, and peroxidase 5-like). Furthermore, based on proteomic data, we suggested that the source of the increased hydrogen peroxide $\left(\mathrm{H}_{2} \mathrm{O}_{2}\right)$ may be due to a protein of the class III peroxidase, which was inhibited in the susceptible genotype. $\mathrm{H}_{2} \mathrm{O}_{2}$ is sensed and probably transduced through overlapping systems related to ascorbate-glutathione and thioredoxin to influence signalling pathways, as revealed by the presence of thioredoxin h-type, ascorbate peroxidase, and guanine nucleotide-binding proteins in the infected resistant plants. Altogether, our data depicted the balance of the oxidative burst and antioxidant enzyme activity in the outcome of this interaction.

Keywords Antioxidant enzymes · Biotic stress · Hydrogen peroxide Phytopathogen - Reactive oxygen species · Sporisorium scitamineum

$\begin{array}{ll}\text { Abbreviations } \\ \text { CAT } & \text { Catalase } \\ \text { GST } & \text { Glutathione S-transferase } \\ \text { MDA } & \text { Malondialdehyde } \\ \text { ROS } & \text { Reactive oxygen species } \\ \text { SA } & \text { Salicylic acid } \\ \text { SOD } & \text { Superoxide dismutase } \\ \text { hpi } & \text { Hours post-inoculation }\end{array}$

\section{Introduction}

Plants have developed an efficient defence system against pathogens (Molina and Kahmann 2007), and an early response is one of the strategies acquired for plants' survival. One of the initial defence reactions in plants after 
pathogen recognition is the increased production of reactive oxygen species (ROS) (Torres 2010; Del Río 2015). This ROS burst, mostly consisting of superoxide anion and hydrogen peroxide $\left(\mathrm{H}_{2} \mathrm{O}_{2}\right)$ at the site of invasion, is regarded as a core component of the early plant immune response (Doehlemann and Hemetsberger 2013). In plant cells, ROS are produced via plasma membrane-localized NADPH oxidase, cell wall peroxidases (class III peroxidases) (Torres 2010), and pathways, such as photosynthesis, photorespiration, and respiration (Gratão et al. 2005). In plants, ROS increase during the infection process by pathogens and, for instance, high concentrations of $\mathrm{H}_{2} \mathrm{O}_{2}$ may contribute to: (1) the strengthening of host cell walls via crosslinking of glycoproteins; (2) lipid peroxidation (membrane damage); (3) pathogen growth inhibition; (4) induction of gene expression; and (5) acting as a signalling molecule (Mittler et al. 1999). In addition, ROS in incompatible interactions culminate in localized cell death, called the hypersensitive response (HR), which may increase the host resistance to biotrophic pathogens (Barna et al. 2012).

However, due to ROS toxicity, antioxidant compounds and enzymes work in conjunction to maintain the steadystate level in plant cells (Apel and Hirt 2004; Gratão et al. 2005). Among these enzymes are superoxide dismutase (SOD, EC 1.15.1.1), catalase, (CAT, EC 1.11.1.6), glutathione S-transferase (GST, EC 2.5.1.18), and others (Ghelfi et al. 2011; Peters et al. 2014). Moreover, it is suggested that plant hormones, such as salicylic acid (SA), jasmonic acid (JA), and abscisic acid (ABA), can influence ROS and antioxidant enzyme activation in this process (Barna et al. 2012).

The biotrophic fungus Sporisorium scitamineum is the causal agent of sugarcane smut, one of the most important diseases of this crop. The teliospore germination of $S$. scitamineum occurs in the bud and internode surface of sugarcane, following the appressorium formation on the inner scales of the young buds. The fungus entrance in the bud meristem occurs between 6 and $36 \mathrm{~h}$ after the teliospore deposition (Sundar et al. 2012). It has been reported that the colonization pattern of $S$. scitamineum differs between resistant and susceptible sugarcane genotypes (Carvalho et al. 2016). In susceptible infected plants, the hyphae are progressively built up within sugarcane tissues, culminating in the formation of a whip-like structure in the primary meristem, compromising culms quality and productivity (Dalvi et al. 2012; Sundar et al. 2012).

The use of resistant varieties is one of the most effective, safe, economical, and environmentally sound approaches to control smut in sugarcane. Some studies have demonstrated that resistance to $S$. scitamineum is associated with chemical barriers, such as the presence of phenylpropanoids, flavonoids (Fontaniella et al. 2002; de Armas et al. 2007), free and conjugated glycoproteins, and an increase of polyamines in sugarcane buds (Millanes et al. 2008). Glycoproteins prevent the correct arrangement of microtubules and cause nuclear fragmentation defects, contributing to germinative failure of teliospores (SánchezElordi et al. 2016). Likewise, resistance may be associated with the presence of trichomes, and the quantity of scales present in buds (da Gloria et al. 1995). Furthermore, resistant plants infected with $S$. scitamineum present an increase of phenylalanine ammonia lyase enzyme activity (de Armas et al. 2007) and cell wall lignification (Santiago et al. 2012). It has been reported in sugarcane that the gene nonexpressor of pathogenesis-related 1 (NPRI) was upregulated (RT-qPCR analysis) in response to SA and $S$. scitamineum (Chen et al. 2012). This gene plays a pivotal role in systemic acquired resistance in plants (Cao et al. 1997). In addition, regarding the oxidative burst, the poxN gene for peroxidase ( $S c S s 36)$ was found to be weakly induced in smut-susceptible plants at $24 \mathrm{~h}$ post-inoculation (hpi), whereas it was upregulated in the resistant plants at 72 hpi ( $\mathrm{LaO}$ et al. 2008). The catalase gene (ScCATl) was associated with $S$. scitamineum, because CAT activity in smut-resistant plants was higher than that in susceptible plants (Su et al. 2014). Recently, Su et al. (2016) revealed that antioxidant enzymes (SOD, CAT, ascorbate peroxidase (APX), and other peroxidases) are useful biochemical indicators of smut resistance. Nevertheless, at present, there are few studies comparing both ROS production and antioxidant enzymes in susceptible- and resistant-sugarcane genotypes upon inoculation with $S$. scitamineum. The present results are expected to provide a better understanding of the sugarcane resistance mechanisms against $S$. scitamineum and should help the management of selection strategies aiming at the development of resistant cultivars.

\section{Materials and methods}

\section{Biological materials and ethical statement}

Two sugarcane genotypes were used to investigate the stress response after inoculation with Sporisorium scitamineum (Syd.) Piepenbr \& Oberw. 2002 (=Ustilago scitaminea Sydow \& P. Sydow) (Piepenbring et al. 2002): clone IAC66-6, the smut-susceptible genotype: (1), and cultivar SP80-3280, the smut-resistant genotype (2) (Fig. S1a). The plants were maintained at the experimental field of the Departamento de Genética, ESALQ, USP. The IAC66-6 clone and public domain variety SP80-3280 were kindly provided by the Centro Avançado de Pesquisa Tecnológica do Agronegócio de Cana, IAC/APTA.

Sporisorium scitamineum SSC39 teliospores were obtained from a diseased plant of the RB925345 
intermediate-resistant variety and were maintained for subsequent experiments in the Genomics Laboratory (ESALQ, USP) (Taniguti et al. 2015).

No special permits were necessary for the teliospores or genotypes used in the experiments, because this project was developed in collaboration with IAC researchers. This work does not involve endangered or protected species.

\section{Inoculation procedure and time-course collection data}

Single-bud sets of 10-month-old healthy plants of both genotypes (Fig. S1a) were surface disinfected and incubated for $16 \mathrm{~h}$ at $28{ }^{\circ} \mathrm{C}$ according to Carvalho et al. (2016). These bud sets were drop inoculated with $20 \mu \mathrm{L}$ of a suspension containing $5 \times 10^{6}$ teliospores $\mathrm{mL}^{-1}$ in $0.01 \%(\mathrm{v} / \mathrm{v})$ Tween20 , whereas controls were inoculated with $20 \mu \mathrm{L}$ of sterile saline solution $(0.85 \%)$ in $0.01 \%$ (v/v) Tween-20 (mock inoculated). All of the inoculated bud sets were maintained in vermiculite at $28^{\circ} \mathrm{C}$ under conditions of $12 \mathrm{~h}$ light $/ 12 \mathrm{~h}$ dark and $85 \%$ relative humidity. Twenty buds of each genotype were collected at each of the time point of 6,12 , 24, 48, and $72 \mathrm{~h}$ post-inoculation (hpi) and were maintained at $-80{ }^{\circ} \mathrm{C}$ until further experiments (Fig. S1b).

\section{Microscopy analysis of fungal structures in plant tissues}

Infected bud scales collected at 6, 12, 24, 48, and $72 \mathrm{hpi}$ were detached from buds and were used to detect fungal structures stained with lactophenol-cotton blue (10 g phenol, $10 \mathrm{~mL}$ glycerol, $10 \mathrm{~mL}$ lactic acid, $0.02 \mathrm{~g}$ cotton blue, and $10 \mathrm{~mL}$ deionized water) (Tuite 1969). Light microscopy analyses were conducted in an Optika B-350 microscope (Optikam B5 digital camera) for all time points. The experiment was performed with three biological replicates. The percentage of spore germination was obtained at 6 and 12 hpi (100 spores were counted for each replicate) (James 1973). The percentage of appressorium was quantified observing at least 100 germinated spores for each replicate (Apoga et al. 2004). Statistical analysis was performed as described in the "Experimental design and statistical analysis".

\section{ROS localization of sugarcane-Sporisorium scitamineum interaction}

Changes in reactive oxygen species (ROS) production in sugarcane bud tissues as a result of $S$. scitamineum infection were assessed. To detect superoxide ions, scales were excised from inoculated and mock-inoculated buds and vacuum infiltrated for $1 \mathrm{~h}$ in $0.1 \%(\mathrm{w} / \mathrm{v})$ nitroblue tetrazolium (NBT) solution in $50 \mathrm{mM}$ potassium phosphate buffer (pH 6.5) (Hückelhoven et al. 2000). Bud scales were then placed into a $0.15 \%$ trichloroacetic acid (TCA) in ethanol and chloroform $(4: 1 ; \mathrm{v} / \mathrm{v})$ solution to make tissues clear in appearance (de Freitas and Stadnik 2012). After $72 \mathrm{~h}$, they were maintained in the dark in $50 \%$ glycerol solution until light- microscopy analysis (Optika B-350; Optikam B5 digital camera). Histochemical detection of $\mathrm{H}_{2} \mathrm{O}_{2}$ was performed according to Hückelhoven et al. (2000), with modifications. A similar protocol was followed to detect superoxide, but NBT was used instead with a $1 \%$ $(\mathrm{w} / \mathrm{v})$ DAB $\left(3,3^{\prime}\right.$ diaminobenzidine) solution in $50 \mathrm{mM}$

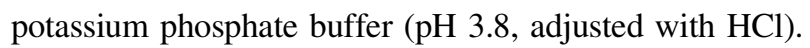

\section{Biochemical analysis}

For all of the biochemical assays described below, 20 sugarcane buds (mock inoculated and inoculated) of each genotype were collected at 6, 12, 24, 48, and 72 hpi. The sugarcane buds were maintained in liquid nitrogen during sampling and were subsequently stored at $-80{ }^{\circ} \mathrm{C}$ until further analysis.

\section{Hydrogen peroxide concentration}

The content of $\mathrm{H}_{2} \mathrm{O}_{2}$ was determined as described by Alexieva et al. (2001). Sugarcane buds (100 mg) were homogenized in $1 \mathrm{~mL}$ of $0.1 \%(\mathrm{~m} / \mathrm{v})$ TCA. The homogenates were centrifuged at $12,000 \mathrm{~g}$ for $10 \mathrm{~min}$ at $4{ }^{\circ} \mathrm{C}$, and $200 \mu \mathrm{L}$ of supernatant was added to $200 \mu \mathrm{L}$ of $100 \mathrm{mM}$ potassium phosphate buffer (pH 7.0) and $800 \mu \mathrm{L}$ of $1 \mathrm{M}$ potassium iodide $(\mathrm{KI})$. The absorbance was read at $390 \mathrm{~nm}$ (Perkin Elmer Lambda 40). The $\mathrm{H}_{2} \mathrm{O}_{2}$ content for all samples was determined using a known $\mathrm{H}_{2} \mathrm{O}_{2}$ concentration curve as a standard. The result was expressed in $\mu \mathrm{mol} \mathrm{g}^{-1}$ fresh weight.

\section{Lipid peroxidation assay}

Membrane damage was determined by estimating the content of thiobarbituric acid reactive substance (TBARS) following the method of Heath and Packer (1968). A total of $100 \mathrm{mg}$ of powdered sugarcane buds was homogenized in $1 \mathrm{~mL}$ of $0.1 \%(\mathrm{w} / \mathrm{v})$ TCA solution and centrifuged at $12,000 \mathrm{~g}$ for $10 \mathrm{~min}$ at $4{ }^{\circ} \mathrm{C}$. Next, $250 \mu \mathrm{L}$ of the supernatant from the TCA extraction was added to $1 \mathrm{~mL}$ of a solution containing $20 \%(\mathrm{w} / \mathrm{v})$ TCA and $0.5 \%(\mathrm{w} / \mathrm{v})$ TBA. The samples were incubated for $30 \mathrm{~min}$ at $95^{\circ} \mathrm{C}$ and centrifuged for $5 \mathrm{~min}$ at $12,000 \mathrm{~g}$. Malondialdehyde (MDA) was monitored by absorbance measurements at 535 and $600 \mathrm{~nm}$ in a Perkin Elmer Lambda 40 spectrophotometer, and the concentration was calculated using an extinction coefficient of $155 \mathrm{mM}^{-1} \mathrm{~cm}^{-1}$. The result was expressed in $\mathrm{nmol} \mathrm{g}^{-1}$ fresh weight. 


\section{Antioxidant enzyme extraction and activity assays}

One gram of fine sugarcane bud powders were homogenized (2:1, buffer volume: fresh weight) in $100 \mathrm{mM}$ potassium phosphate buffer $(\mathrm{pH} 7.5)$ containing $1 \mathrm{mM}$ EDTA, 3 mM DL-dithiothreitol (DTT), 2 mM $\beta$-mercaptoethanol, and $5 \%(\mathrm{w} / \mathrm{w})$ polyvinylpolypyrrolidone (PVPP). The homogenates were centrifuged at $12,000 \mathrm{~g}$ for $30 \mathrm{~min}$ at $4{ }^{\circ} \mathrm{C}$, and the supernatants were stored in separate aliquots at $-80{ }^{\circ} \mathrm{C}$ prior to enzymatic analysis. The concentration of protein was determined using bovine serum albumin as the standard (Bradford 1976).

\section{SOD activity staining}

SOD activity staining was carried out as described by Beauchamp and Fridovich (1971) and optimized by Azevedo et al. (1998). The non-denaturing 12\% PAGE gels were loaded with $30 \mu \mathrm{g}$ of biological extract protein, and electrophoresis was carried out with a constant current until migration was completed. After non-denaturing PAGE separation, the gel was incubated in the dark in $50 \mathrm{mM}$ potassium phosphate buffer $(\mathrm{pH} 7.8)$ containing $1 \mathrm{mM}$ EDTA, $0.05 \mathrm{mM}$ riboflavin, $0.1 \mathrm{mM}$ nitroblue tetrazolium, and $0.3 \% \mathrm{~N}, \mathrm{~N}, \mathrm{~N}^{\prime}, \mathrm{N}^{\prime}$-tetramethylethylenediamine. One unit of bovine liver SOD (Sigma) was used as a positive control of activity. After $30 \mathrm{~min}$, the gels were rinsed with distilled deionized water and then were illuminated in water until the development of achromatic bands of SOD activity on a purple-stained gel. SOD isoenzyme characterization was performed as described by Giannopolitis and Ries (1977) and as modified by Azevedo et al. (1998). SOD isoenzymes were distinguished by their sensitivity to inhibition by $2 \mathrm{mM}$ potassium cyanide and $5 \mathrm{mM}$ hydrogen peroxide.

\section{CAT total activity determination}

CAT activity was assayed as described by Aebi (1984) and modified by Gratão et al. (2012) at $25^{\circ} \mathrm{C}$ in a reaction mixture of $1 \mathrm{~mL}$ of $100 \mathrm{mM}$ potassium phosphate buffer ( $\mathrm{pH}$ 7.5) containing $2.5 \mu \mathrm{L}$ of $\mathrm{H}_{2} \mathrm{O}_{2}$ (3\% solution). The reaction was initiated by the addition of $25 \mu \mathrm{L}$ of protein extract, and the activity was determined by following the decomposition of $\mathrm{H}_{2} \mathrm{O}_{2}$ according to the changes in absorbance at $240 \mathrm{~nm}$. CAT activity is expressed as $\mu \mathrm{mol} \min ^{-1} \mathrm{mg}^{-1}$ protein.

\section{GST total activity determination}

The methodologies described by Booth et al. (1961) and modified by Ghelfi et al. (2011) were used to determined GST activity. The activity was assayed spectrophotometrically at $30{ }^{\circ} \mathrm{C}$ in a mixture containing $900 \mu \mathrm{L}$ of $100 \mathrm{mM}$ potassium phosphate buffer (pH 6.5), $25 \mu \mathrm{L}$ of $40 \mathrm{mM}$ 1-chloro-2,4-dinitrobenzene (CDNB), $50 \mu \mathrm{L}$ of $1 \mathrm{mM}$ $\mathrm{GSH}$, and $25 \mu \mathrm{L}$ of enzyme extract. The reaction mixture was followed by monitoring the increase in absorbance at $340 \mathrm{~nm}$ over $3 \mathrm{~min}$. GST activity was expressed as $\mu \mathrm{mol} \mathrm{min}^{-1} \mathrm{mg}^{-1}$ protein.

\section{Protein preparation}

In view of the cytological and biochemical changes induced during the infection process, we sought to analyse proteins associated with an oxidative burst. The time point selected for protein extraction corresponded to the increase in $\mathrm{H}_{2} \mathrm{O}_{2}$ and lipid peroxidation concentration (72 hpi) detected in the resistant genotype. Proteins were extracted from sugarcane buds according to the protocol described by Hurkman and Tanaka (1986) with modifications. Bud samples $(50 \mathrm{mg})$ were finely powdered in liquid nitrogen and homogenized in $800 \mu \mathrm{L}$ of extraction buffer $(1 \%$ PVPP, 0.7 M sucrose, 0.1 M KCl, 0.5 M Tris-HCl pH 7.5, $500 \mathrm{mM}$ EDTA, $1 \mathrm{mM}$ (PMSF), and 2\% b-mercaptoethanol). Phenol $(800 \mu \mathrm{L})$ was added, and the mixture was homogenized for $30 \mathrm{~min}$ at $4{ }^{\circ} \mathrm{C}$ and finally centrifuged at $10,000 \mathrm{~g}$ for $30 \mathrm{~min}$. The upper phenol phase was removed and re-extracted two times with extraction buffer as above. Proteins were precipitated from the final phenol phase with two volumes of saturated ammonium acetate in methanol overnight at $4{ }^{\circ} \mathrm{C}$ and were pelleted by centrifugation at $10,000 \mathrm{~g}$ for $30 \mathrm{~min}$. The protein pellets were solubilized in lysis buffer ( $7 \mathrm{M}$ urea and $2 \mathrm{M}$ thiourea). The concentration of protein was determined using bovine serum albumin as the standard (Bradford 1976).

\section{Mass spectrometry MS/MS and data analysis}

For protein analysis, an aliquot of $4.5 \mu \mathrm{L}$ of proteins from peptide digestion was separated in C18 (100 mm $6100 \mathrm{~mm}$ ) RP-nano UPLC (nanoAcquity, Waters) coupled with a Q-Tof Premier mass spectrometer (Waters) with a nanoelectrospray source at a flow rate of $0.6 \mu \mathrm{L} / \mathrm{min}$. The gradient was $2-90 \%$ acetonitrile in $0.1 \%$ formic acid over $45 \mathrm{~min}$. The nanoelectrospray voltage was set to $3.5 \mathrm{kV}$, a cone voltage of $30 \mathrm{~V}$, and the source temperature was set to $100{ }^{\circ} \mathrm{C}$. The instrument was operated in the 'top three' mode, in which one MS spectrum is acquired followed by MS/MS of the top three most-intense peaks detected. After MS/MS fragmentation, the ion was placed on an exclusion list for $60 \mathrm{~s}$ and for the analysis of endogenous cleavage peptides, real-time exclusion was used. The spectra were acquired using the software MassLynx v.4.1, and the raw data files were converted to a peak list format (mgf) without summing the scans by the software Mascot 
Distiller v.2.3.2.0, 2009 (Matrix Science Ldt.) and searched against (9747 sequences, 3345,870 residues) using Mascot engine v.2.3.01 (Matrix Science Ltd.), with carbamidomethylation as fixed modifications, oxidation of methionine as variable modification, one trypsin missed cleavage, and a tolerance of $0.1 \mathrm{Da}$ for both precursor and fragment ions. The Scaffold software was used to calculate the normalized spectral counts and to validate peptide and protein identifications (Nesvizhskii et al. 2003), considering the scoring parameters (95\% of peptide confidence level identification, $99 \%$ peptide probability, and at least two unique peptides) to obtain a false discovery rate (FDR) of less than $1 \%$ for proteins and peptides.

\section{RNA extraction and gene expression analysis}

The time points selected for gene expression analysis corresponded to appressorium formation (24 hpi) of $S$. scitamineum in the susceptible genotype and the increase in $\mathrm{H}_{2} \mathrm{O}_{2}$ and lipid peroxidation concentration (72 hpi) in the resistant genotype. The genes analyzed were selected from previous work based on differential expression (analysed by RNAseq) in plants infected with $S$. scitamineum (Schaker et al. 2016). In addition, other genes coding for proteins identified as present or absent during the proteomic assay were selected for gene expression analysis. RNA extraction was performed using Trizol ${ }^{\circledR}$ (Sigma) and the Direct-zol ${ }^{\mathrm{TM}}$ RNA MiniPrep Kit (Zymo Research) according to the manufacturer's instructions. Total RNA was treated with DNAse (Sigma), and RNA quality was verified in agarose gel. The primers were manually designed and the quality verified using Gene Runner (http://www.generunner.net/) and Beacon Designer ${ }^{\mathrm{TM}}$ Free Edition (http://www.premierbiosoft.com) softwares (Table S1). To confirm the absence of genomic DNA contamination, PCR assays were performed with samples. All RT-qPCRs were conducted in the 7500 Fast Real-Time PCR System (Applied Biosystems) using GoTaq ${ }^{\circledR}$ OneStep RT-qPCR System Kit (Promega). A reaction mixture containing $50 \mathrm{ng}$ of RNA, $6.5 \mu \mathrm{L}$ of GoTaq $^{\circledR}$ qPCRMaster Mix, $0.2 \mu \mathrm{M}$ of each primer, $0.25 \mu \mathrm{L}$ of $\operatorname{GoScript}^{\mathrm{TM}} \mathrm{RT}$ Mix, and nuclease-free water to a final volume of $12.5 \mu \mathrm{L}$ was used for three biological replicates and two technical replicates. The cycling conditions were as follows: $37{ }^{\circ} \mathrm{C}$ for $15 \mathrm{~min}, 95^{\circ} \mathrm{C}$ for $10 \mathrm{~min}$; 40 cycles of $95^{\circ} \mathrm{C}$ for $10 \mathrm{~s}$, $60{ }^{\circ} \mathrm{C}$ for $30 \mathrm{~s}$, and $72{ }^{\circ} \mathrm{C}$ for $30 \mathrm{~s}$. Primer specificity was confirmed obtaining the dissociation curve for every reaction. Sugarcane housekeeping genes encoding for polyubiquitin (Papini-Terzi et al. 2005) and 14:3:3 (Rocha et al. 2007) were used to normalize expression signals. PCR efficiencies and $\mathrm{Ct}$ values were obtained using the LinReg PCR program (Ramakers et al. 2003). The relative changes in the gene expression ratios were calculated using the
REST software (Pfaffl et al. 2004). Control samples (mockinoculated plants) were used as calibrators.

\section{Experimental design and statistical analysis}

The experiment was performed in a completely randomized design, and each treatment was conducted on three biological replicates. The significance of the observed differences was verified using Student's $t$ test $(P<0.05)$. All statistical analyses were carried out using the $\mathrm{R}$ software (URL http://www.r-project.org).

\section{Results}

\section{Sporisorium scitamineum development delayed in sugarcane tissues of resistant plants}

To understand the initial sugarcane reaction to $S$. scitamineum, we investigated the infection process of the fungus in smut-susceptible and -resistant plants. Sugarcane bud scales were used to analyse the production of ROS in a time-course experiment, at 6, 12, 24, 48, and $72 \mathrm{hpi}$, monitored by light microscopy. The results showed that the fungus presented well established infection stages and differentiated structures in both the analysed genotypes (susceptible and resistant). These modifications comprised filament formation upon recognition of the host surface and the development of infection structures, such as the appressorium. At $6 \mathrm{hpi}, 81 \%$ of teliospores were germinated in the susceptible genotype (Fig. 1a), forming promycelium (Fig. 2a-1, b-1); however, in the resistant genotype SP80-3280, teliospore germination had initiated only in $36 \%$ of teliospores (Fig. 2a-6, b-6), reaching a maximum rate at $12 \mathrm{hpi}(53 \%)$ (Fig. 1a).

Appressorium formation was quantified by observing lactophenol-cotton blue-stained fungal filaments on bud scale surfaces. In the susceptible genotypes, $71 \%$ of the hyphal tips developed an appressorium (Figs. 1b, 2a-3) at $24 \mathrm{hpi}$, whereas in the resistant genotype, only $43 \%$ of the tips developed an appressorium later at 48 hpi (Fig. 1b, 2b9). At $72 \mathrm{hpi}$, the formation of an extensive network of filaments in both genotypes was observed (Fig. 2a-10, b-10).

\section{Sugarcane-resistant plants over-produce ROS earlier after $S$. scitamineum inoculation}

The production of superoxide anion and $\mathrm{H}_{2} \mathrm{O}_{2}$ in infected bud scales was determined by the in situ oxidation of nitroblue tetrazolium (NBT) and 3,3'-diaminobenzidine (DAB), respectively. The results revealed that the main ROS compound produced is $\mathrm{H}_{2} \mathrm{O}_{2}$, and the response 
Fig. 1 Teliospore germination and appressorium formation of S. scitamineum on sugarcane bud scale surface in smutsusceptible and -resistant genotypes. a Teliospore germination (\%).

b Appressorium formation (\%). Bars represent the standard deviations of three independent biological replicates. Asterisk represents statistically significant differences $(P<0.05)$ between the smutsusceptible and -resistant genotypes
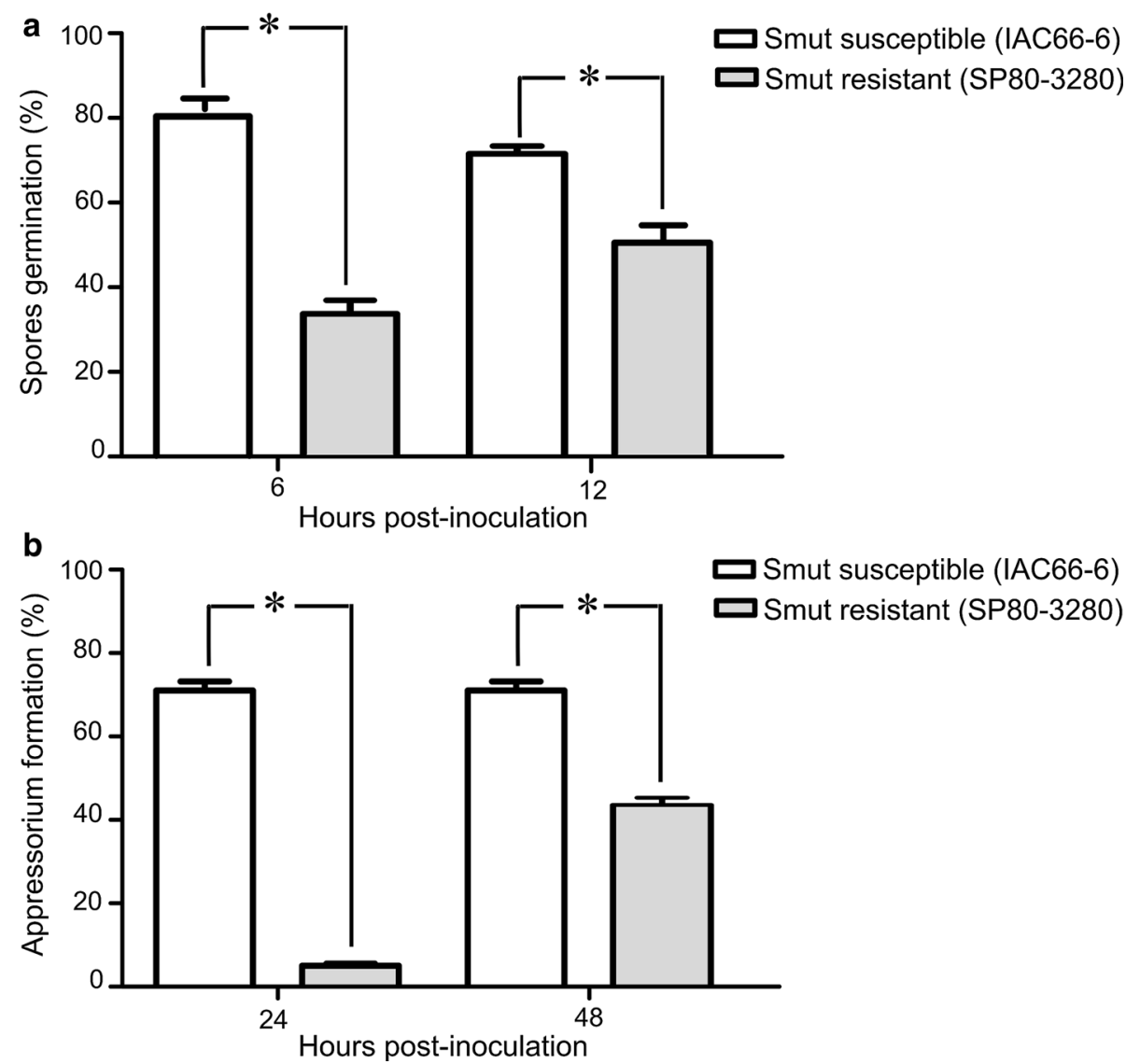

became more evident at $72 \mathrm{hpi}$ for both genotypes (Fig. 2b-10, b-10). This is the time when the network of filaments is well established for both genotypes. However, for resistant plants, $\mathrm{H}_{2} \mathrm{O}_{2}$ accumulation was initiated earlier at $6 \mathrm{hpi}$ along with teliospore germination (Fig. 2b-6). Furthermore, $\mathrm{H}_{2} \mathrm{O}_{2}$ accumulation was also observed in the plant epidermal cells in direct contact with the appressorium at 48 hpi (Fig. 2b-9). As the colonization progressed, the fungal hyphae started to produce internal vesicular bodies, probably containing $\mathrm{H}_{2} \mathrm{O}_{2}$ (Fig. 2b-8, b-2, b-3). These vesicles were evident in hyphal growth at 12 and $24 \mathrm{hpi}$ in the susceptible genotypes and at $24 \mathrm{hpi}$ in the resistant one. However, at the other time points analysed for the genotypes, there was no accumulation of $\mathrm{H}_{2} \mathrm{O}_{2}$ in fungal vesicles.

The production of superoxide anion was also evaluated in sugarcane tissues infected with $S$. scitamineum. The results showed that the plant cells of the resistant genotype produced superoxide at 6 and 12 hpi (Fig. 2a-6, a-7). At these time points, the presence of superoxide anion was restricted to the surrounding areas of the promycelium hyphal tips. Superoxide production was not observed at any other time point analysed of the resistant genotype as well as at any observed time of the susceptible genotype using the proposed technique.
Biochemical assays allowed the quantification of $\mathrm{H}_{2} \mathrm{O}_{2}$ produced in both inoculated and non-inoculated buds of the two genotypes. The accumulation of $\mathrm{H}_{2} \mathrm{O}_{2}$ at 6,48 , and 72 hpi in smut-resistant plants was higher $(23,22$, and $70 \%$, respectively) than that in mock controls (Fig. 3a); however, for the other time points analysed, changes in the $\mathrm{H}_{2} \mathrm{O}_{2}$ content were not observed. Likewise, smut-susceptible buds did not exhibit the accumulation of $\mathrm{H}_{2} \mathrm{O}_{2}$ at all time points analysed (Fig. 3a).

\section{Sporisorium scitamineum infection induces lipid peroxidation in resistant sugarcane}

We examined the extension of oxidative damage in sugarcane buds challenged with $S$. scitamineum by determining the content of lipid peroxidation (malondialdehyde, MDA). The results showed that the MDA content in inoculated plants of the susceptible genotype was not altered significantly throughout the experiment (Fig. 3b). Although a similar result was observed for the resistant genotype, an increase of $41 \%$ in the MDA content was detected at 72 hpi (Fig. 3b). There was a major intrinsic difference in MDA content between the smut-susceptible and -resistant genotypes regardless inoculation, with the susceptible genotype exhibiting a much higher lipid 


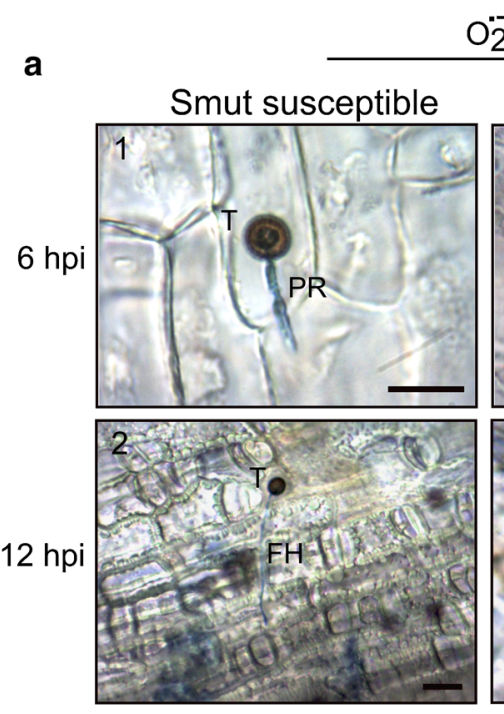

0
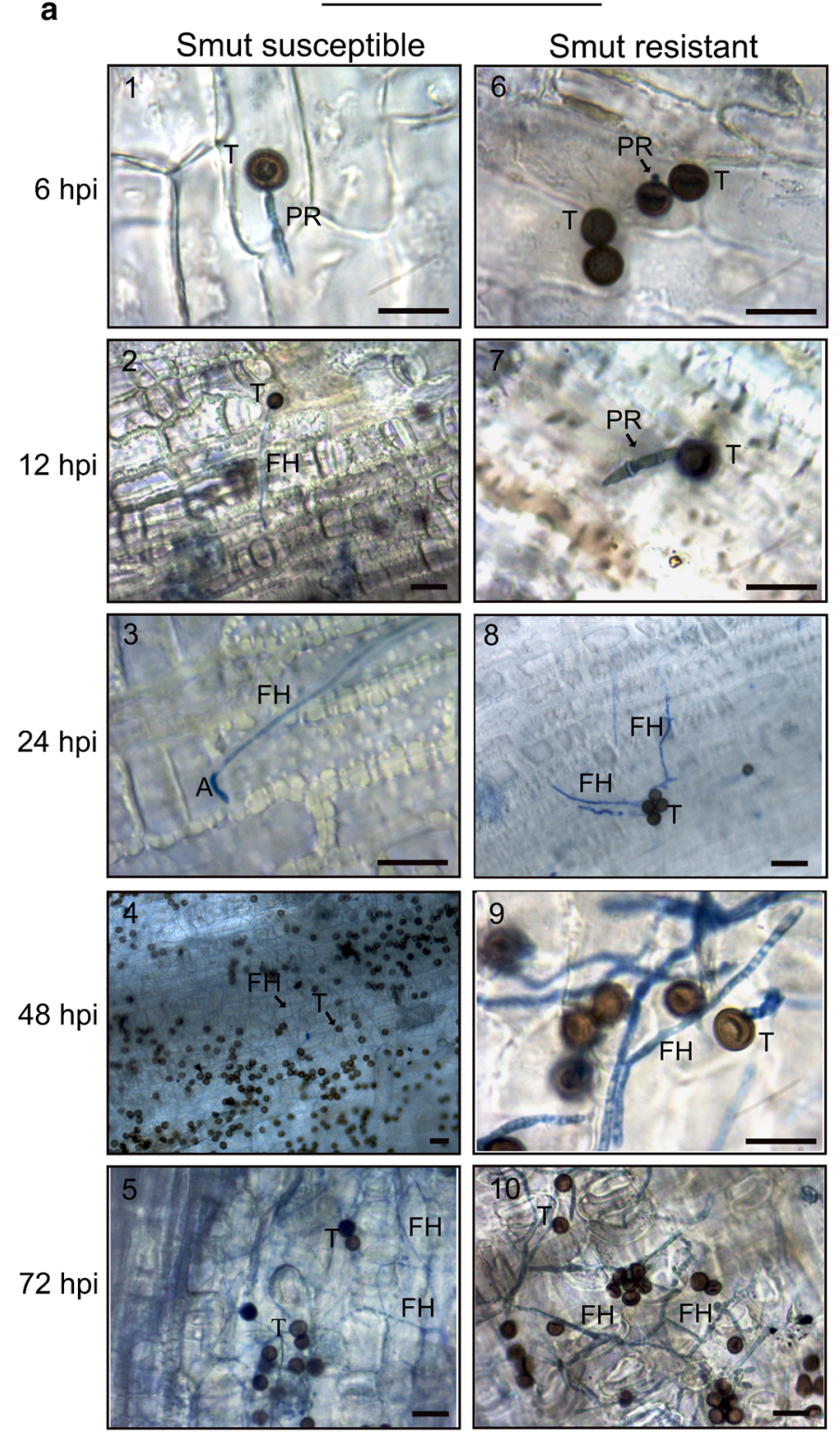

b

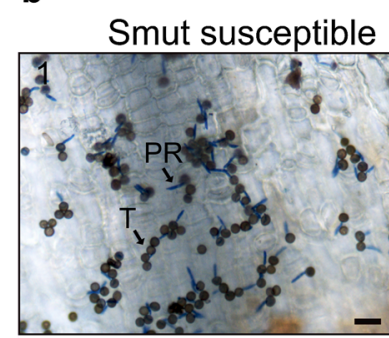

$\mathrm{H}_{2} \mathrm{O}_{2}$
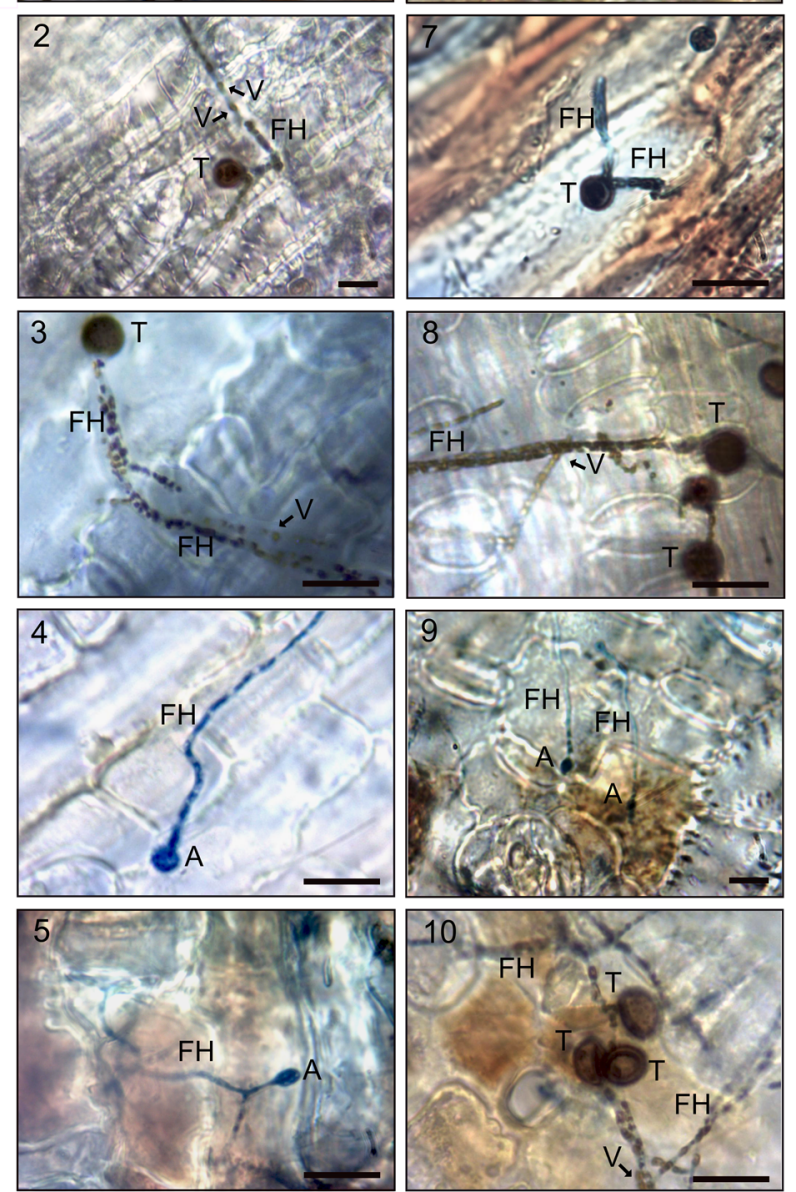

Fig. 2 Microscopic analysis of the $S$. scitamineum infection sites on inoculated sugarcane bud scale and ROS produced on sugarcane bud scales during S. scitamineum infection in a time course from 6 to 72 hpi. a Inoculated bud scales were stained with nitroblue tetrazolium (NBT) to detect the production of superoxide anion (formation of dark blue formazans) in sugarcane smut-susceptible

peroxidation rate (about 70\%) during the entire course of the experiment (Fig. 3b).

\section{Sporisorium scitamineum alters the activities of antioxidant enzymes in sugarcane}

The overall enzyme activity patterns related to ROS scavenging (SOD, CAT, and GST) were distinct in the resistant and susceptible genotypes. SOD activity was (numbers of 1-5) and -resistant plants (numbers of 6-10). b Inoculated bud scales were stained with 3,3'-diaminobenzidine (DAB) to detect the production of $\mathrm{H}_{2} \mathrm{O}_{2}$ (DAB polymerization, brown) in sugarcane smut-susceptible (numbers of 1-5) and -resistant plants (numbers of 6-10). A appressorium, $F H$ fungal hyphae, $P R$ promycelium, $T$ teliospore, $V$ vesicular bodies. Bar $100 \mu \mathrm{m}$

determined by non-denaturing PAGE staining for isoenzyme identification (Fig. 4a, b). The results revealed the existence of five isoenzymes characterized as $\mathrm{Mn} / \mathrm{SODs}$ (SOD I, II, and III) and $\mathrm{Cu}-\mathrm{Zn} / \mathrm{SODs}$ (SOD IV and V) in the smut-susceptible genotype (Fig. 4a), and ten isoenzymes identified as Mn/SODs (SOD I, II, III, and IV) and $\mathrm{Cu}-\mathrm{Zn} / \mathrm{SODs}$ (V, VI, VII, VIII, IX, and X) in the smutresistant genotype (Fig. 4b). However, SOD activity did not exhibit any major visible changes or specific alterations 
Fig. 3 Detection of $\mathrm{H}_{2} \mathrm{O}_{2}$ and lipid peroxidation caused by $S$. scitamineum in sugarcane buds. a Effects of $S$. scitamineum infection on the $\mathrm{H}_{2} \mathrm{O}_{2}$ content ( $\mu \mathrm{mol} \mathrm{g}{ }^{-1}$ fresh weight) (quantitative results). b Effects of this fungus on malondialdehyde (MDA) content (nmol g ${ }^{-1}$ fresh weight) in susceptible- and resistantsugarcane genotypes over the time course from 6 to $72 \mathrm{hpi}$. Values represent the means from three independent biological replicates \pm SD. Asterisk represents statistically significant differences $(P<0.05)$ between control buds (mock inoculated) and inoculated buds
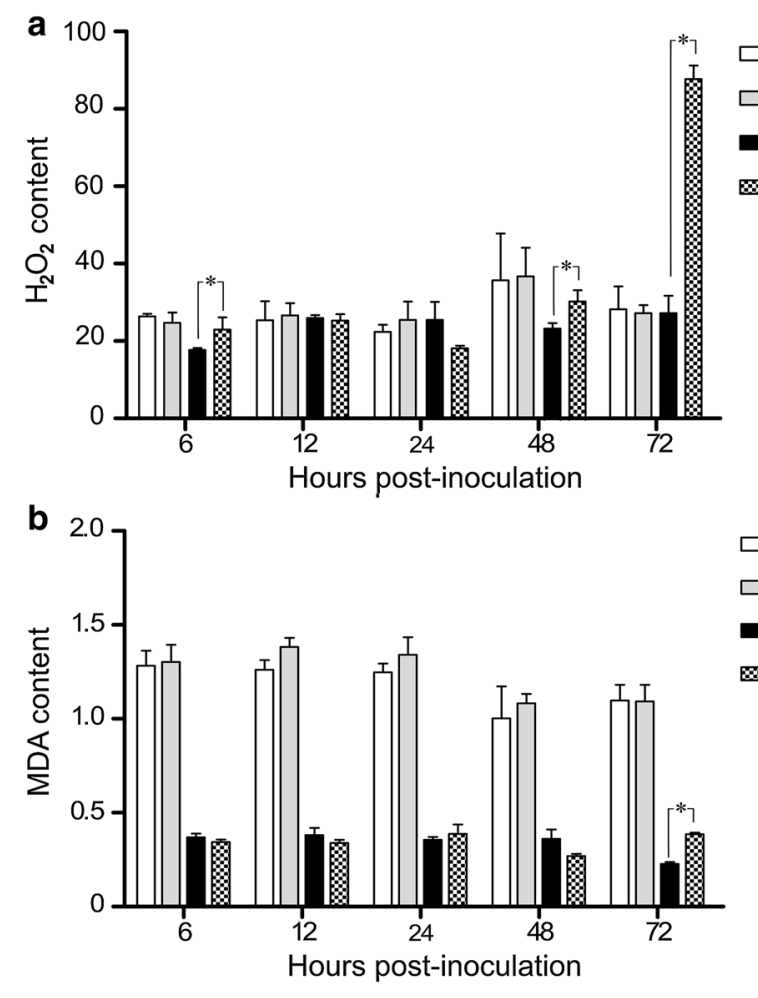

Fig. 4 Effects of $S$.

scitamineum infection on the activity of superoxide dismutase (SOD). a Activity staining for SOD following non-denaturing PAGE from smut-susceptible genotypes over the time course from 6 to 72 hpi. b Activity staining for SOD following nondenaturing PAGE from smutresistant genotypes over the time course from 6 to $72 \mathrm{hpi}$. The first lane is a bovine SOD standard, and arrows indicate sequentially numbered SOD bands for smut-susceptible (IV) and smut-resistant (I-X) plants. $C$ represents control buds and $I$ represents inoculated buds
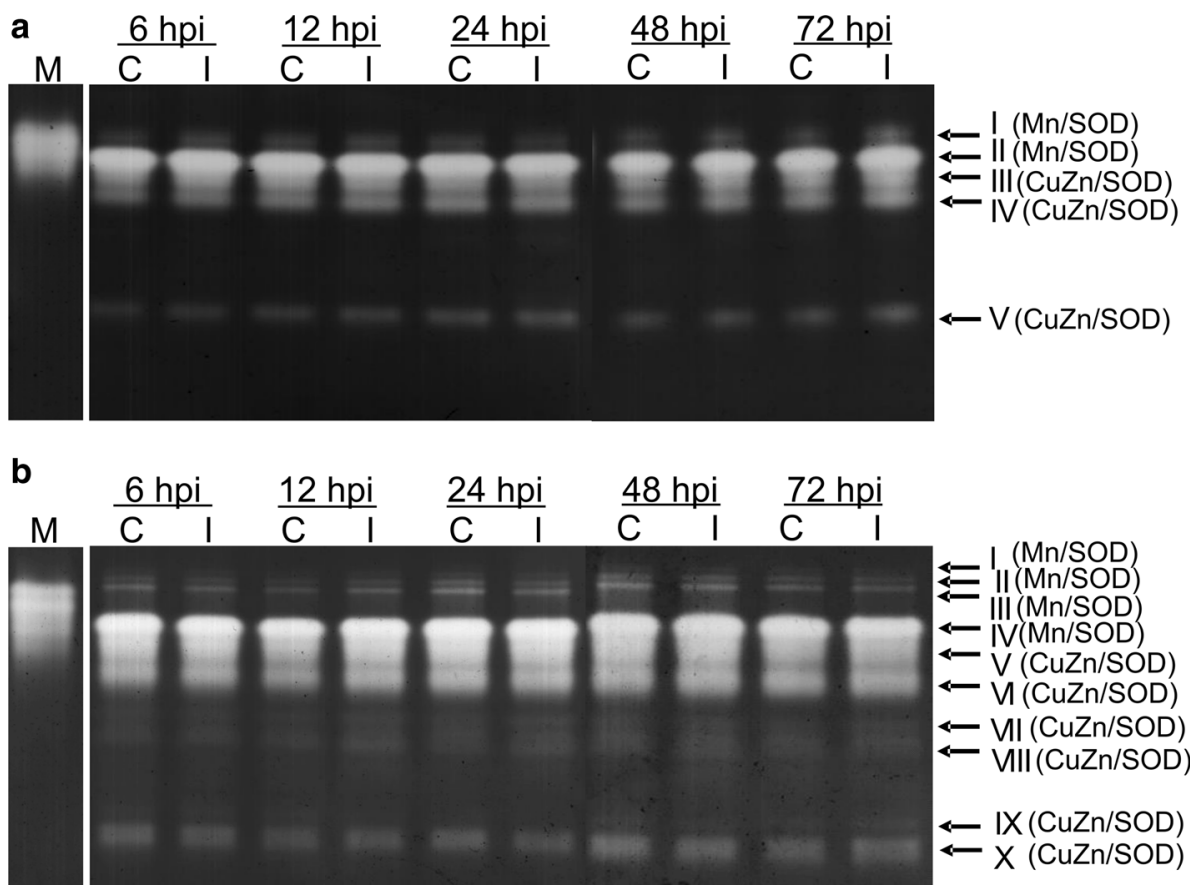

in the expression of the distinct isoenzymes in any of the genotypes in response to the inoculation with $S$. scitamineum. The five isoenzymes present in the susceptible genotype were also present in the resistant one (susceptible SOD II, III, IV, and V corresponding to resistant SOD IV, $\mathrm{V}$, VI, and X), three of them (IAC66-6 II, III, and IV;
SP8032-80 IV, V, and VI) accounting for most of the SOD activity.

CAT total activity was not altered in the susceptible genotype throughout the experiment (Fig. 5a). By contrast, for the resistant genotype, a decrease in CAT activity was observed at $12 \mathrm{hpi}(67 \%)$ and at $72 \mathrm{hpi}$ 
Fig. 5 Effects of $S$. scitamineum infection on the total specific activity of catalase (CAT) and glutathione S-transferase (GST) in susceptible- and resistantsugarcane genotypes over the time course from 6 to 72 hpi. a Total specific activity of CAT ( $\mu \mathrm{mol} \mathrm{min}^{-1} \mathrm{mg}^{-1}$ protein). b Total specific activity of GST (units $\min ^{-1} \mathrm{mg}^{-1}$ protein). Values represent the means from three independent biological replicates \pm SD. Asterisk represents statistically significant differences $(P<0.05)$ between control (mock inoculated) buds and inoculated buds
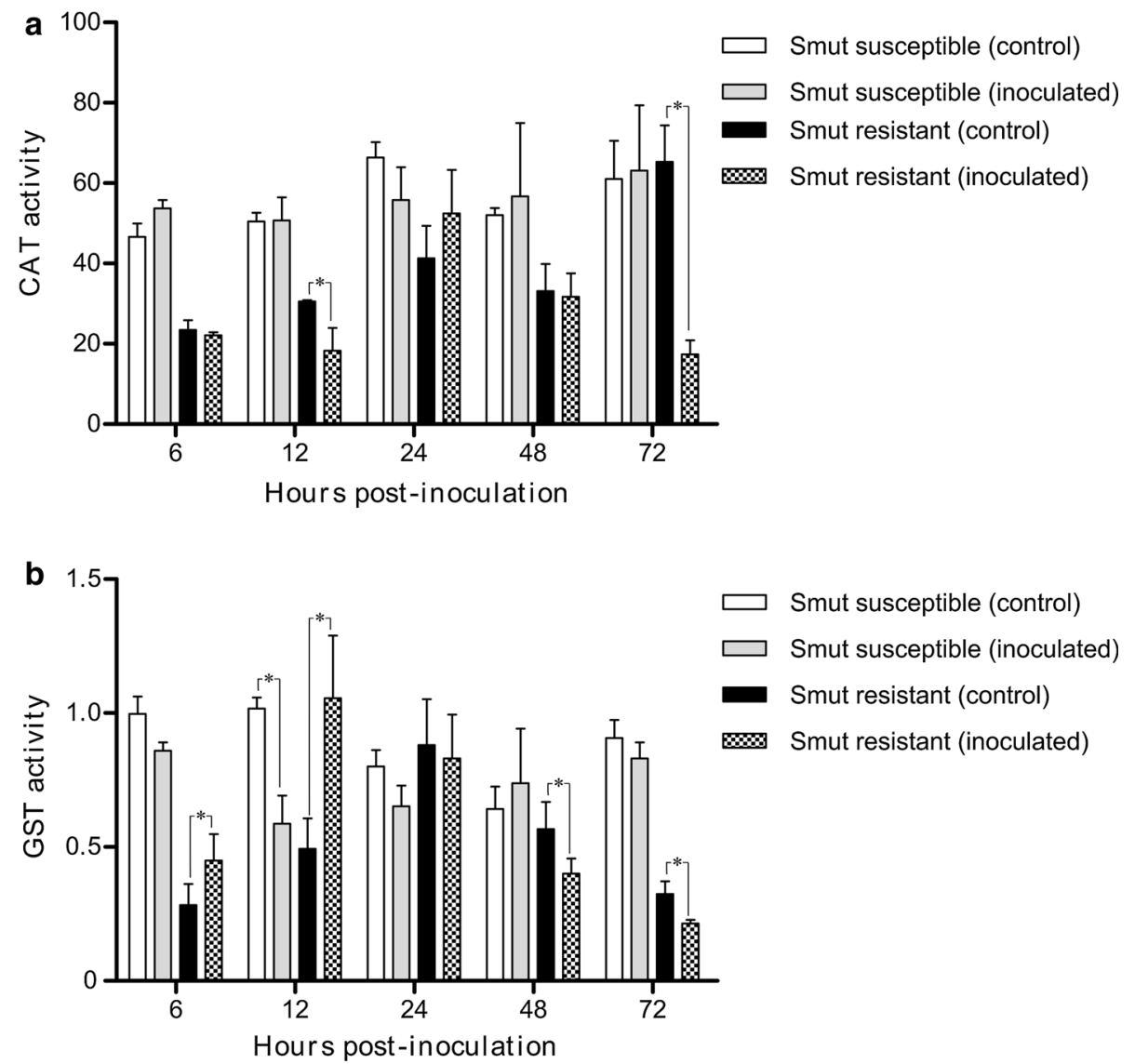

Hours post-inoculation
(275\% decrease) (Fig. 5a). CAT activity was consistently higher, especially at 6 and $12 \mathrm{hpi}$, in the susceptible genotype than in the resistant genotype independent of the inoculation (Fig. 5a). However, high CAT activity was also detected in the resistant non-inoculated plants at $72 \mathrm{hpi}$. At this time, the sugarcane bud is going through the germination process. In germinating seeds, active mitochondria are one of the major sources of ROS, generating superoxide, and subsequently $\mathrm{H}_{2} \mathrm{O}_{2}$. Chloroplasts can also generate ROS at the beginning of seed development as well as peroxisomes (El-Maarouf-Bouteau and Bailly 2008). Thus, we assume that the CAT activity in the resistant non-inoculated might be associated with the germination process of sugarcane bud.

Total GST activity exhibited contrasting results between the two genotypes. The susceptible genotype exhibited an early decrease ( $42 \%$ at 12 hpi) (Fig. 5b); however, the resistant genotype increased the activity even earlier $(37 \%$ at $6 \mathrm{hpi}$ ), reaching its maximum value at $12 \mathrm{hpi}(70 \%$ increase). These changes co-occurred with the teliospore initial germination and maximum germination rates, respectively (Fig. 2a-6, b-6). However, GST activity in the resistant genotype decreased 30 and $24 \%$ at 48 and 72 hpi, respectively (Fig. 5b).

\section{Sugarcane proteins associated with oxidative burst are induced or repressed in response to $S$. scitamineum infection}

Based on the results of protein identification and functional categorization (Barnabas et al. 2016), four proteins associated with oxidative burst were detected from a set containing 38 proteins ( 4 proteins from susceptible genotype and 34 proteins from resistant genotype) that were particularly present or absent between the two genotypes (Fig. 6; Table 1). The complete list of present or absent proteins consistently detected in replicates is presented in Table S2. Among these proteins, a cationic peroxidase spc4-like (peroxidase III class) was repressed in the susceptible genotype (Table S2). Three proteins were induced in response to infection in the resistant genotype: ascorbate peroxidase, thioredoxin h-type, and guanine nucleotidebinding protein subunit beta-like (Table S2).

\section{Gene expression analysis}

The ROS-related marker genes were selected based on previously obtained RNAseq data (Schaker et al. 2016) and on the protein sequences induced and repressed by the 

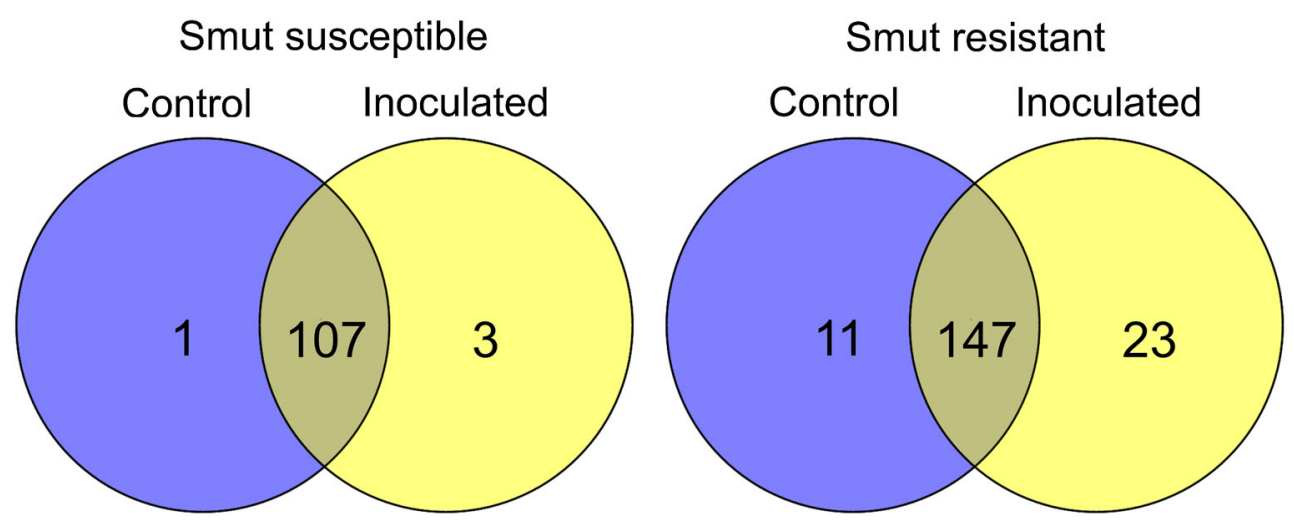

Fig. 6 Venn diagram of induced or repressed proteins in susceptible- and resistant-sugarcane genotypes inoculated with $S$. scitamineum (72 hpi)

Table 1 Induced or repressed proteins related to ROS metabolism at $72 \mathrm{hpi}$

\begin{tabular}{|c|c|c|c|c|c|c|c|c|}
\hline \multirow[t]{2}{*}{ Treatment $^{\mathrm{a}}$} & \multirow[t]{2}{*}{ Protein description $^{b}$} & \multirow{2}{*}{$\begin{array}{l}\text { Protein } \\
\text { threshold }^{\mathrm{c}}\end{array}$} & \multicolumn{6}{|c|}{$\%$ Sequence coverage $^{\mathrm{d}}$} \\
\hline & & & $\mathrm{C} 1$ & $\mathrm{C} 2$ & $\mathrm{C} 3$ & Inoc 1 & Inoc 2 & Inoc3 \\
\hline Smut resistant (inoculated) & Ascorbate peroxidase & $0.9 \%$ & 0 & 0 & 0 & $10.00 \%$ & $10.00 \%$ & 0 \\
\hline Smut resistant (inoculated) & $\begin{array}{l}\text { Guanine nucleotide-binding } \\
\text { protein subunit beta-like } \\
\text { protein a }\end{array}$ & $0.9 \%$ & 0 & 0 & 0 & $18.09 \%$ & $15.09 \%$ & \\
\hline Smut resistant (inoculated) & Thioredoxin h-type & $1 \%$ & 0 & 0 & 0 & $25.4 \%$ & $25.4 \%$ & $31.5 \%$ \\
\hline $\begin{array}{l}\text { Smut susceptible (mock } \\
\text { inoculated) }\end{array}$ & Class III peroxidase & $1 \%$ & $14.5 \%$ & $14.5 \%$ & $9.44 \%$ & 0 & 0 & 0 \\
\hline
\end{tabular}

${ }^{a}$ Corresponds to treatment that protein is present

b Protein description based on UniProt Knowledgebase

${ }^{c}$ Protein threshold corresponds to false discovery rate (FDR)

d $\%$ Sequence coverage represents the percentage of all the amino acids in the protein sequence that were covered by identified peptides detected in the sample. C1, C2, and C3 represent control 1, 2, and 3, respectively. Inoc1, Inoc2, and Inoc3 represent inoculated 1, 2, and 3, respectively

fungus identified in this work. A total of ten genes were analysed at two time points: 24 and 72 hpi (Fig. 7). These two time points were chosen, because $24 \mathrm{hpi}$ coincided with appressorium formation in the susceptible genotype, and 72 hpi coincided with the increase in $\mathrm{H}_{2} \mathrm{O}_{2}$ and lipid peroxidation concentration in the resistant genotype. At 24 hpi (Fig. 7a), the genes encoding SOD and the two GSTs exhibited a similar regulation pattern in both genotypes, in which the genes of SOD and GSTs were downregulated. The genes encoding GDP and PRX4 were significantly upregulated only in the resistant genotype. By contrast, the cat genes along with the genes coding for thioredoxin and POX5 peroxidases showed opposite regulation. They were all upregulated in the resistant genotype but were downregulated in the susceptible one. At $72 \mathrm{hpi}$ (Fig. 7b), genes encoding SOD remained downregulated for both genotypes, and genes encoding PRX4 remained upregulated for the resistant genotype. However, the CAT genes and genes for peroxidases POX5 and TRX h had their expression regulation inverted. They were all downregulated in the resistant genotype, but were upregulated in the susceptible one. The gene for GDP was significantly downregulated at $72 \mathrm{hpi}$ in the susceptible genotype (Fig. 7b).

\section{Discussion}

To characterize the sugarcane responses in the early stages of interaction, we performed histochemical and biochemical studies and assessed the gene expression profile and protein identification associated with the antioxidant system of sugarcane genotypes susceptible and resistant to smut. Similar to other smut species, S. scitamineum is a biotrophic fungus that during the early stage of infection penetrates plant tissues colonizing the primary meristem (Sundar et al. 2012). To depict the events related to ROS, we used a resistant SP80-3280 genotype, which is considered highly resistant to smut and is largely cultivated in Brazil, and the IAC66-6 genotype, which is highly susceptible to smut and is maintained only for research purposes (Carvalho et al. 2016). 

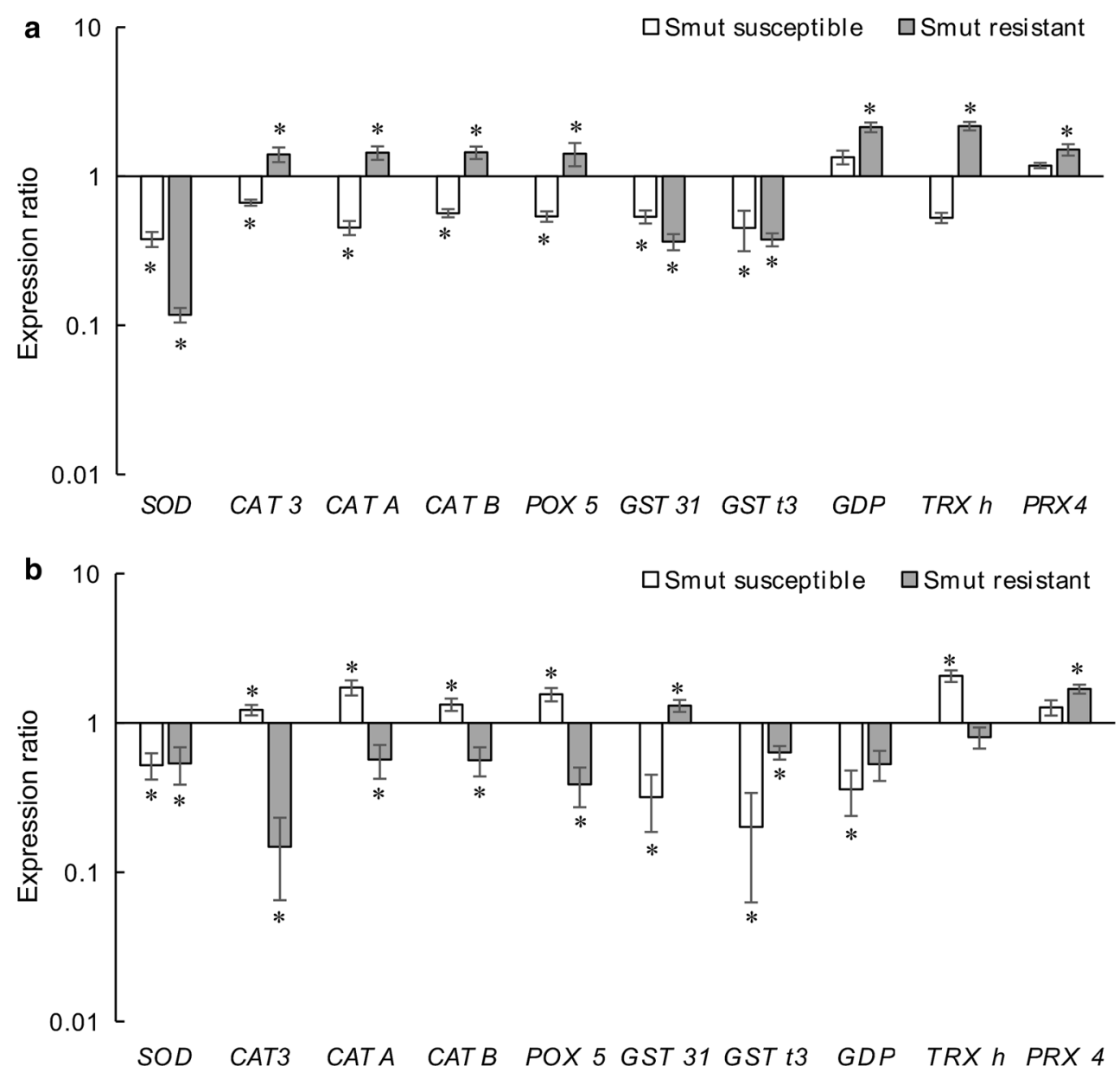

Fig. 7 Expression profiles of superoxide dismutase (SOD-comp186491_c0_seq 1), catalase 3 (CAT3-comp189288_c1_seq 1), catalase A (CATA-comp189288_c0_seq 1), catalase B (CATBcomp191235_c0_seq 1), peroxidase 5-like (POX5-comp127311_c0_seq 1), glutathione S-transferase 31 (GST31-comp179663_c0_seq 1), glutathione S-transferase t3 (GST t3comp198747_c0_seq 1), guanine nucleotide-binding protein a (GDP-Sb09g027690.1|PACid:1981757), thioredoxin h like (TRX

Buds of these two genotypes were clearly distinguished by the format, hardness, and pigmentation (Fig. S1a). Our data revealed that teliospore germination was delayed in the resistant genotype; however, it still proceeded, reaching its maximum at $12 \mathrm{hpi}$. It is noteworthy that fungal colonization was achieved for both genotypes using the inoculation method that did not injure sugarcane tissues. Following the germination results, appressorium formation was also delayed in resistant plants but was not completely impaired.

ROS production causes a direct toxic effect to the pathogen along with localized injuries to the plant cell membrane (Torres 2010), which delays or impairs fungal colonization. Although some previous studies ( $\mathrm{LaO}$ et al. 2008; Song et al. 2013; Su et al. 2014) have reported the relevance of the oxidative burst to counteract fungal h-evm.model.scga7_unitig_341686.1), and peroxidase III class (PRX4-evm.model.scga7_uti_cns_0172034.2) genes associated with the antioxidant system in smut-susceptible and -resistant genotypes by RT-qPCR analysis. a Gene expression at 24 hpi. b Gene expression at 72 hpi. Statistical analysis was performed using the REST ${ }^{\circledR}$ software. Asterisk represents genes differentially expressed by RT-qPCR $(P<0.05)$

colonization, we were able to relate each fungal developmental stage to the variation of the plant responses. Regarding histochemical studies, our results demonstrated that $S$. scitamineum markedly induced $\mathrm{H}_{2} \mathrm{O}_{2}$ accumulation at 6,48 , and 72 hpi in the inoculated buds of the resistant genotype. These three time points were related to the three phases of fungal development: phase I, coinciding with initial spore germination at $6 \mathrm{hpi}$ (beginning of promycelium formation); phase II: proceeding at $48 \mathrm{hpi}$, at the moment of the accumulation of $\mathrm{H}_{2} \mathrm{O}_{2}$ surrounding the appressorium; and the third phase at $72 \mathrm{hpi}$ when an extensive net of fungal hyphae was observed and $\mathrm{DAB}$ staining revealed $\mathrm{H}_{2} \mathrm{O}_{2}$ spread over the epidermal cells of the bud surface $\left(\mathrm{H}_{2} \mathrm{O}_{2}\right.$ increased by $70 \%$ compared with the control). This triphasic type of $\mathrm{H}_{2} \mathrm{O}_{2}$ accumulation in incompatible interactions has been described for other 
monocots involving interactions such as those of Blumeria graminis $\mathrm{f}$. sp. hordei-infected barley (Hückelhoven and Kogel 2003) and Septoria tritici-infected wheat (Shetty et al. 2007). Other pathosystems seem to rely on two phases of an ROS-associated response to pathogens (Lamb and Dixon 1997; Torres 2010). These differences presumably are determined by the host genotype, as well as by the pathogen infection process (Shetty et al. 2007). In our study, for the susceptible genotype, $\mathrm{H}_{2} \mathrm{O}_{2}$ accumulation was first detected only at $72 \mathrm{hpi}$, suggesting that, in this genotype, the recognition of the pathogen and oxidative burst is more delayed and weaker.

Similar to ROS production, lipid peroxidation is a biochemical marker of oxidative stress (Gratão et al. 2005). It has been proposed that lipid peroxidation is a key process for membrane alteration in plants (Lamb and Dixon 1997), and in many cases, this response is efficient against biotrophic pathogens that depend on living cells to survive (Koeck et al. 2011). In our study, the smut-resistant genotype showed increased levels of MDA content at $72 \mathrm{hpi}$, a finding that was not detected for the susceptible genotype. Interestingly, the reduced GST antioxidant enzyme activity and particularly the CAT activity, probably contributed to the increased levels of $\mathrm{H}_{2} \mathrm{O}_{2}$, leading consequently to this increased lipid peroxidation. CAT is referred as a key $\mathrm{H}_{2} \mathrm{O}_{2}$-scavenging enzyme in plants and is generally localized in the peroxisomes, where most of the cellular $\mathrm{H}_{2} \mathrm{O}_{2}$ is produced as well as several signalling molecules derived from $\beta$-oxidation, including salicylic acid (SA) (del-Río and López-Huertas 2016). For instance, CAT activity may be inhibited by the action of SA during $\mathrm{HR}$, elevating $\mathrm{H}_{2} \mathrm{O}_{2}$ levels, and inducing the expression of defence genes in response to pathogens (Mittler et al. 1999). In addition, inhibition of CAT can convert SA into a free radical, which can also initiate lipid peroxidation (Durner and Klessig 1996). It was also described that SA signalling is the major pathway activated by biotrophic pathogens (Glazebrook 2005) associated with the early defence response of sugarcane to $S$. scitamineum (Chen et al. 2012). These results lead us to propose a key role of $\mathrm{H}_{2} \mathrm{O}_{2}$ in the sugarcane early defence response to smut, probably in association with SA. In addition, the MDA data showed that the constitutive antioxidant system between the two sugarcane genotypes was notably different. In all treatments, the smut resistant exhibited $70 \%$ lower MDA content that of the in smut-susceptible genotype independent of conditions applied.

The ROS-scavenging systems play an important role in managing ROS generated in the plant-pathogen interaction (Torres 2010). SOD catalyses the dismutation of superoxide anion to $\mathrm{H}_{2} \mathrm{O}_{2}$ and $\mathrm{O}_{2}$, and represents the first line of defence against ROS (Gratão et al. 2005). In the present study, SOD activity did not exhibit any major alterations that could be due to the inoculation in either the resistant or susceptible genotype. No major alterations in the band intensity or specific induction or repression of isoenzymes were observed between the control and inoculated plants. Conversely, the two genotypes exhibited a different number of isoenzymes, explained by the genetic background, but not the infection with $S$. scitamineum or resistance/susceptibility. The isoenzyme pattern observed for the SP80-3280-resistant genotype agrees with the previous report by Fornazier et al. (2002) who used the same genotype to study cadmium-induced stress in sugarcane. These authors also identified a large number of SOD isoenzymes with the same ones also accounting for most of the SOD activity observed. Because SOD dismutates the superoxide radicals into $\mathrm{H}_{2} \mathrm{O}_{2}$ and $\mathrm{O}_{2}$, the results suggest that, at least under the conditions tested, the changes in the $\mathrm{H}_{2} \mathrm{O}_{2}$ accumulation observed (Fig. 2b-6, b-9, 2b-10) cannot be explained by changes in SOD activity.

The increase in CAT activity in the buds of resistantsugarcane plants (Yacheng 05-179) infected with S. scitamineum in the early stages of interaction (6 and $24 \mathrm{hpi}$ ) was previously detected, whereas the susceptible genotype (Liucheng 03-182) did not alter the expression levels during the analysis ( $\mathrm{Su}$ et al. 2014). According to the authors, there is a positive correlation between the CAT activity and sugarcane resistance to smut. Our data corroborate these previous results regarding the susceptible genotype. However, CAT activity decreased at 12 and 72 hpi in the smut-resistant genotype used here, suggesting that resistant genotypes may respond differently than previously suggested to $S$. scitamineum infection. Our work revealed that, particularly at $72 \mathrm{hpi}$, the infected buds had an increased $\mathrm{H}_{2} \mathrm{O}_{2}$ content and lipid peroxidation and a decreased CAT activity.

Likewise, GSTs are responsible for antioxidant activity, reducing damage caused by pathogens through the removal of lipid hydroperoxides produced by the peroxidation of membranes (Dean et al. 2005; Ghelfi et al. 2011). In the present study, GST activity was increased in the infected resistant genotype at 6 and 12 hpi probably contributing to the inhibition of lipid peroxidation. We conclude that this increased GST activity may be associated with smut resistance, because we did not detect alterations in the susceptible genotypes, except at $12 \mathrm{hpi}$, in which GST activity was decreased. In other pathosystems, the GST increased activity has also been associated with pathogen resistance (Debona et al. 2012; Fortunato et al. 2015).

We also analysed susceptible and resistant sugarcane plants at $72 \mathrm{hpi}$ at the protein level. Thirty-nine proteins were detected as induced or inhibited in sugarcane in response to $S$. scitamineum infection, and four of these were oxidative-stress related. In this first proteomic attempt, we did not use a quantitative approach; instead, 
proteins were identified as particularly present in only one of the two genotypes tested upon infection. The protein cationic peroxidase spc4-like (evm.model.scga7_uti_cns_0172034.2) (classified as class III peroxidase) was inhibited in susceptible buds. In addition, this same protein-encoding gene tested via RT-qPCR was upregulated in the smut-resistant genotype at 24 and $72 \mathrm{hpi}$; however, in the smut-susceptible genotype, its expression did not change throughout the time points analysed. We speculate that $S$. scitamineum caused the inhibition of this peroxidase probably through the action of effectors. The pathosystem involving maize and the smut fungus Ustilago maydis expressed the PEP1 effector that inhibits this same peroxidase (identity $86 \%$ ) in susceptible plants, leading to

a

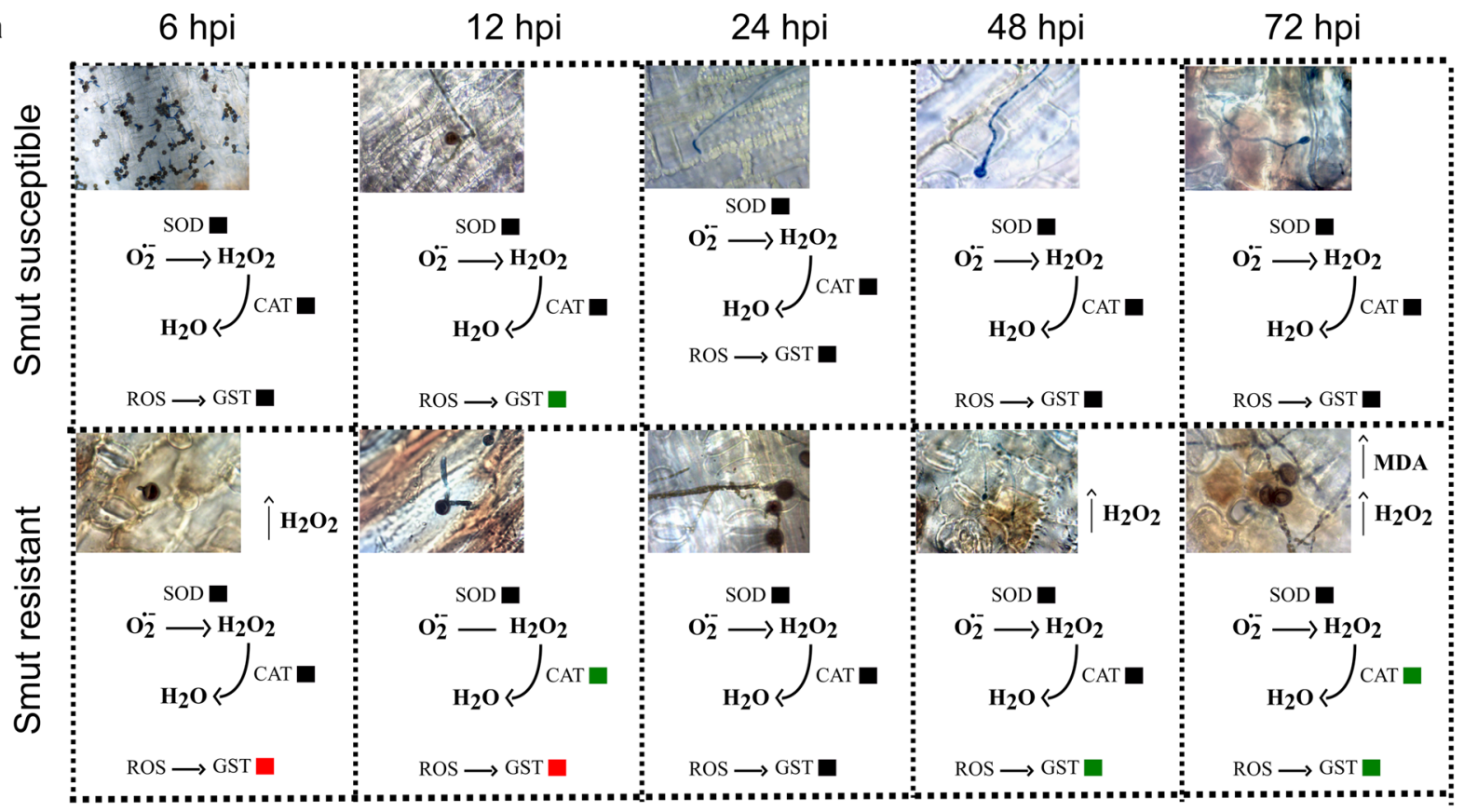
$6 \mathrm{hpi}$ $12 \mathrm{hpi}$ $24 \mathrm{hpi}$ $48 \mathrm{hpi}$ $72 \mathrm{hpi}$

b

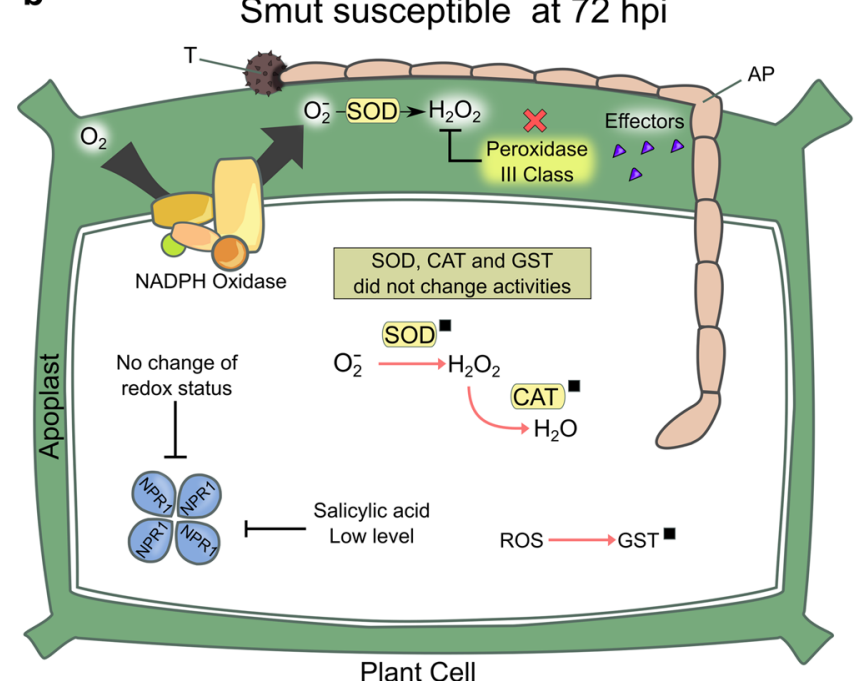

Fig. 8 General view of ROS metabolism of sugarcane buds inoculated with $S$. scitamineum. a Summary of the antioxidant system, oxidative-stress markers, and infection process of $S$. scitamineum on sugarcane bud scales in a time-course experiment $(6,12,24,48$, and $72 \mathrm{hpi}$ ) based on the data obtained in the present study. Superoxide dismutase (SOD); catalase (CAT); glutathione S-transferase (GST); lipid peroxidation (MDA); $\mathrm{H}_{2} \mathrm{O}_{2}$; thioredoxin enzyme (Trx); nonexpressor of pathogenesis-related 1 oligomeric complex (NPR1); hypersensitive response (HR). Green squares indicate decreases in

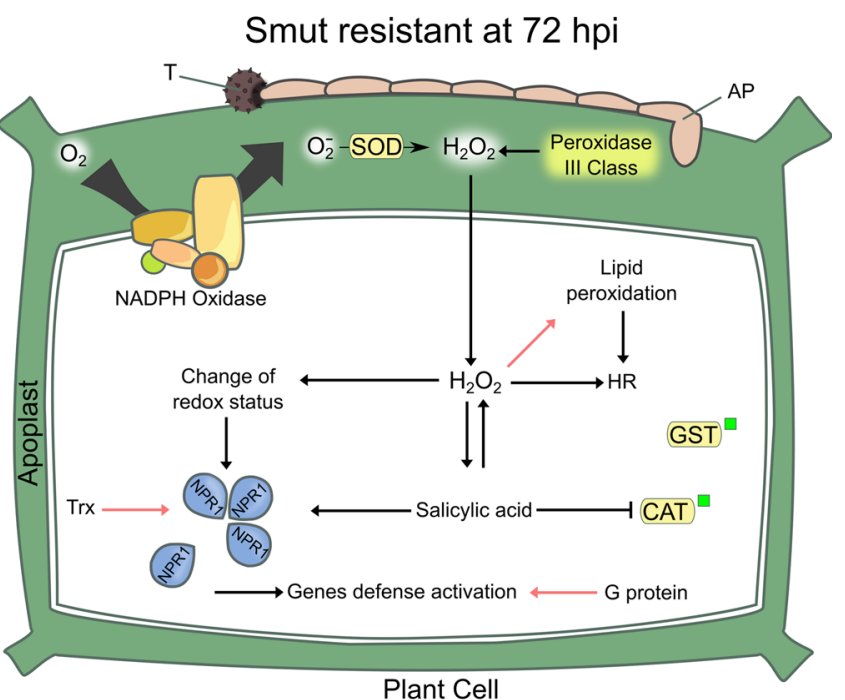

enzymatic activity; red squares indicate increases in enzymatic activity; black squares indicate no alterations. b Overview of the mechanisms associated with ROS and antioxidant enzymes of susceptible and resistant sugarcane inoculated with $S$. scitaminum at 72 hpi. Red arrows represent results from this study. Green squares indicate decreases in enzymatic activity; black squares indicate no alterations. Symbol indicates "x" repression (only in smut-susceptible plants). $T$ teliospore, $A p$ appressorium. All changes are relative to the mock control 
blockade of the oxidative burst and suppression of the early immune responses of maize (Hemetsberger et al. 2012). The gene encoding an orthologue of PEP1 is present in the S. scitamineum genome (Hemetsberger et al. 2015). We also identified in the infected sugarcane-resistant genotype proteins, such as thioredoxin h-type (evm.model.scga7_unitig_341686.1), guanine nucleotide-binding protein, subunit beta-like protein a (Sb09g027690.11PACid:1981757 classified as G protein), and ascorbate peroxidase (Sb02g044060.1IPACid:1959988), which were not detected in the susceptible genotypes. Thioredoxins can regulate the redox status of proteins through thiol-disulphide exchange reactions (Sevilla et al. 2015). In plantpathogen interactions, thioredoxins are required to catalyse the conversion of the SA-induced nonexpressor of pathogenesis-related (PR) genes 1 (NPRl) into a monomer and to activate defence responses (Tada et al. 2008). Previous data have shown that sugarcane plants infected with $S$. scitamineum upregulated NPRI (Chen et al. 2012). In addition, $\mathrm{G}$ proteins are associated with defence signalling in plants (Liu et al. 2013), in which the activation of these proteins $(\mathrm{G} \beta)$ occurs in response to pathogen elicitors, leading to ROS increase (Torres et al. 2013) and the synthesis-related (PR) proteins (Beffa et al. 1995).

We further investigated the expression of genes at 24 and 72 hpi that were identified by histo-biochemical and proteomic data regarding the processes of oxidative burst and antioxidative defence. These two points were relevant and markedly different considering the two genotypes analysed. The transcription profiles of marker genes of the antioxidant system followed the pattern of ROS management discussed here between sugarcane-susceptible and resistant genotypes. The response of the smut-resistant genotype was earlier (at $24 \mathrm{hpi}$ ), showing high transcript accumulation after infection for several of the analysed genes; however, in the smut-susceptible genotype, these same genes were downregulated. Conversely, these same genes were upregulated in the susceptible genotype later at 72 hpi. Previous RNAseq data from sugarcane cultivars resistant (Yacheng 05-179) and susceptible ("ROC"22) to $S$. scitamineum revealed that the genes associated with resistance in the resistant cultivar were earlier expressed (24-48 hpi) than those detected for smut-susceptible cultivars (28-120 hpi) (Que et al. 2014). Other regulatory processes may be involved, because the expression of genes encoding the antioxidant enzymes did not necessarily coincide with the enzyme response. Moreover, other antioxidant enzymes may also be involved in the stress response and must be considered in future studies. In particular, we suggest that special attention should be given to apoplastic class III peroxidases and the enzymes of the ascorbate-glutathione cycle.
In conclusion, we described the sugarcane response regarding the oxidative burst induced by $S$. scitamineum using a combination of molecular and biochemical tools to identify candidate genes that allow relevant information on resistance to smut. At the initial step of smut infection, ROS production and antioxidant enzymes have different outcomes between the susceptible- and resistant-sugarcane genotypes. Our results demonstrated that fungal developmental stages within sugarcane tissues (smut resistant) impose an earlier oxidative-burst response by reducing the activity of antioxidant enzymes and significantly increasing $\mathrm{H}_{2} \mathrm{O}_{2}$ accumulation, resulting in severe lipid peroxidation (Fig. 8a, b). This timely response in the sugarcane-resistant genotype is stronger at $72 \mathrm{hpi}$. The fungal hyphae upon exposure to the plant response accumulated $\mathrm{H}_{2} \mathrm{O}_{2}$ in vesicles throughout its extension. This is an effect that needs to be further explored. It is also clear that the different enzymes analysed may respond differently depending on the period tested, inoculation and genotype. However, regardless of the genotypes, fungal colonization is achieved for both genotypes at $72 \mathrm{hpi}$.

Author contribution statement Conceived and designed the experiments: CBMV LPP GC RAA. Performed the experiments: LPP MBV. Analyzed the data: CBMV LPP RAA. Contributed reagents/materials/analysis tools: CBMV RAA SC. Wrote the paper: LPP GC RAA SC CBMV. Provided expertise and editing: CBMV RAA. All authors read and approved the manuscript.

Acknowledgments The authors thank the Centro Nacional de Pesquisa em Energia e Materiais (CNPEM) for performing the mass spectrometry analysis. The authors also thank the technical support of Elaine Vidotto.

\section{Compliance with ethical standards}

Financial support The authors acknowledge the support of the Brazilian institutions FAPESP and CNPq (CNPq 443827/2014-1; FAPESP 2015/07112-4 [CBM-V], FAPESP 2009/54676-0 [RAA] and fellowships to LPP (2013/15014-7), GC (CNPq 159973/2012-0), CBMV (CNPq 303965/2015-0), RAA (CNPq 302540/2011-3), and MBV (CNPq 142736/2011-2).

\section{References}

Aebi H (1984) Catalase in vitro. Methods Enzymol 105:121-126 Alexieva V, Sergiev I, Mapelli S, Karanov E (2001) The effect of drought and ultraviolet radiation on growth and stress markers in pea and wheat. Plant Cell Environ 24:1337-1344

Apel K, Hirt H (2004) Reactive oxygen species: metabolism, oxidative stress, and signal transduction. Annu Rev Plant Biol 55:373-399

Apoga D, Barnard J, Craighead HG, Hoch HC (2004) Quantification of substratum contact required for initiation of Colletotrichum graminicola appressoria. Fungal Genet Biol 41:1-12 
Azevedo RA, Alas RM, Smith RJ, Lea PJ (1998) Response of antioxidant enzymes to transfer from elevated carbon dioxide to air and ozone fumigation, in the leaves and roots of wild-type and a catalase-deficient mutant of barley. Physiol Plant 104:280-292

Barna B, Fodor J, Harrach BD et al (2012) The Janus face of reactive oxygen species in resistance and susceptibility of plants to necrotrophic and biotrophic pathogens. Plant Physiol Biochem 59:37-43

Barnabas L, Ashwin NMR, Kaverinathan K et al (2016) Proteomic analysis of a compatible interaction between sugarcane and Sporisorium scitamineum. Proteomics 16:1111-1122

Beauchamp C, Fridovich I (1971) Superoxide dismutase: improved assays and an assay applicable to acrylamide gels. Anal Biochem 44:276-287

Beffa R, Szell M, Meuwly P et al (1995) Cholera toxin elevates pathogen resistance and induces pathogenesis-related gene expression in tobacco. EMBO J 14:5753-5761

Booth J, Boyland E, Sims P (1961) An enzyme from rat liver catalysing conjugations with glutathione. Biochem J 79:516-524

Bradford MM (1976) A rapid and sensitive method for the quantitation of microgram quantities of protein utilizing the principle of protein-dye binding. Anal Biochem 72:248-254

Cao H, Glazebrook J, Clarke JD et al (1997) The Arabidopsis NPRI gene that controls systemic acquired resistance encodes a novel protein containing ankyrin repeats. Cell 88:57-63

Carvalho G, Quecine MC, Longatto DP et al (2016) Sporisorium scitamineum colonisation of sugarcane genotypes susceptible and resistant to smut revealed by GFP-tagged strains. Ann Appl Biol 169:329-341. doi:10.1111/aab.12304

Chen J-W, Kuang J-F, Peng G et al (2012) Molecular cloning and expression analysis of a NPR1 gene from sugarcane. Pak J Bot 44:193-200

da Gloria BA, Albernas MC, Amorim L (1995) Structural characteristics of buds of sugarcane cultivars with different levels for resistance in smut. J Plant Dis Prot 102:502-508

Dalvi SG, Vasekar VC, Yadav A et al (2012) Screening of promising sugarcane somaclones for agronomic traits, and smut resistance using PCR amplification of inter transcribed region (ITS) of Sporisorium scitaminae. Sugar Tech 14:68-75

de Armas R, Santiago R, Legaz M-E, Vicente C (2007) Levels of phenolic compounds and enzyme activity can be used to screen for resistance of sugarcane to smut (Ustilago scitaminea). Australas Plant Pathol 36:32-38

de Freitas MB, Stadnik MJ (2012) Race-specific and ulvan-induced defense responses in bean (Phaseolus vulgaris) against Colletotrichum lindemuthianum. Physiol Mol Plant Pathol 78:8-13

Dean JD, Goodwin PH, Hsiang T (2005) Induction of glutathione S-transferase genes of Nicotiana benthamiana following infection by Colletotrichum destructivum and $C$. orbiculare and involvement of one in resistance. J Exp Bot 56:1525-1533

Debona D, Rodrigues FÁ, Rios JA, Nascimento KJT (2012) Biochemical changes in the leaves of wheat plants infected by Pyricularia oryzae. Phytopathology 102(12):1121-1129

del Río LA (2015) ROS and RNS in plant physiology: an overview. J Exp Bot 66:2827-2837

del Río L, López-Huertas E (2016) ROS generation in peroxisomes and its role in cell signaling. Plant Cell Physiol 57(7):1364-1376

Doehlemann G, Hemetsberger C (2013) Apoplastic immunity and its suppression by filamentous plant pathogens. New Phytol 198:1001-1016

Durner J, Klessig DF (1996) Salicylic acid is a modulator of tobacco and mammalian catalases. J Biol Chem 271:28492-28501

El-Maarouf-Bouteau H, Bailly C (2008) Oxidative signaling in seed germination and dormancy. Plant Signal Behav 3(3):175-182
Fontaniella B, Márquez A, Rodríguez CW et al (2002) A role for sugarcane glycoproteins in the resistance of sugarcane to Ustilago scitaminea. Plant Physiol Biochem 40:881-889

Fornazier RF, Ferreira RR, Pereira GJG et al (2002) Cadmium stress in sugar cane callus cultures: effect on antioxidant enzymes. Plant Cell Tiss Organ 71:125-131

Fortunato AA, Debona D, Bernardeli AMA, Rodrigues FÁ (2015) Changes in the antioxidant system in soybean leaves infected by Corynespora cassiicola. Phytopathology 105(8):1050-1058

Ghelfi A, Gaziola SA, Cia MC et al (2011) Cloning, expression, molecular modelling and docking analysis of glutathione transferase from Saccharum officinarum. Ann Appl Biol 159:267-280

Giannopolitis CN, Ries SK (1977) Superoxide dismutases: I. occurrence in higher plants. Plant Physiol 59:309-314

Glazebrook J (2005) Contrasting mechanisms of defense against biotrophic and necrotrophic pathogens. Annu Rev Phytopathol 43:205-227

Gratão PL, Polle A, Lea PJ, Azevedo RA (2005) Making the life of heavy metal-stressed plants a little easier. Funct Plant Biol 32:481-494

Gratão PL, Monteiro CC, Carvalho RF et al (2012) Biochemical dissection of diageotropica and Never ripe tomato mutants to Cd-stressful conditions. Plant Physiol Biochem 56:79-96

Heath RL, Packer L (1968) Photoperoxidation in isolated chloroplasts. Arch Biochem Biophys 125:189-198

Hemetsberger C, Herrberger C, Zechmann B et al (2012) The Ustilago maydis effector Pep1 suppresses plant immunity by inhibition of host peroxidase activity. PLoS Pathogol 8:e1002684. doi:10.1371/journal.ppat.1002684

Hemetsberger C, Mueller AN, Matei A et al (2015) The fungal core effector Pep1 is conserved across smuts of dicots and monocots. New Phytol 206:1116-1126

Hückelhoven R, Kogel K-H (2003) Reactive oxygen intermediates in plant-microbe interactions: who is who in powdery mildew resistance? Planta 216:891-902

Hückelhoven R, Fodor J, Trujillo M, Kogel K-H (2000) Barley Mla and Rar mutants compromised in the hypersensitive cell death response against Blumeria graminis f.sp. hordei are modified in their ability to accumulate reactive oxygen intermediates at sites of fungal invasion. Planta 212:16-24

Hurkman WJ, Tanaka CK (1986) Solubilization of plant membrane proteins for analysis by two-dimensional gel electrophoresis. Plant Physiol 81:802-806

James GL (1973) Smut spore germination on sugarcane internode surfaces. Proceedings of The South African Sugar Technologists' Association, pp 179-180

Koeck M, Hardham AR, Dodds PN (2011) The role of effectors of biotrophic and hemibiotrophic fungi in infection. Cell Microbiol 13:1849-1857

Lamb C, Dixon RA (1997) The oxidative burst in plant disease resistance. Annu Rev Plant Physiol Plant Mol Biol 48:251-275

$\mathrm{LaO} \mathrm{M}$, Arencibia AD, Carmona ER et al (2008) Differential expression analysis by cDNA-AFLP of Saccharum spp. after inoculation with the host pathogen Sporisorium scitamineum. Plant Cell Rep 27:1103-1111

Liu J, Ding P, Sun T et al (2013) Heterotrimeric G proteins serve as a converging point in plant defense signaling activated by multiple receptor-like kinases. Plant Physiol 161:2146-2158

Millanes A-M, Vicente C, Legaz M-E (2008) Sugarcane glycoproteins bind to surface, specific ligands and modify cytoskeleton arrangement of Ustilago scitaminea teliospores. J Plant Interact 3:95-110

Mittler R, Herr EH, Orvar BL et al (1999) Transgenic tobacco plants with reduced capability to detoxify reactive oxygen intermediates are hyperresponsive to pathogen infection. Proc Natl Acad Sci USA 96:14165-14170 
Molina L, Kahmann R (2007) An Ustilago maydis gene involved in $\mathrm{H}_{2} \mathrm{O}_{2}$ detoxification is required for virulence. Plant Cell 19:2293-2309

Nesvizhskii AI, Keller A, Kolker E, Aebersold R (2003) A statistical model for identifying proteins by tandem mass spectrometry. Anal Chem 75:4646-4658

Papini-Terzi FS, Rocha FR, Vêncio RZN et al (2005) Transcription profiling of signal transduction-related genes in sugarcane tissues. DNA Res 12:27-38

Peters LP, Carvalho G, Martins PF et al (2014) Differential responses of the antioxidant system of ametryn and clomazone tolerant bacteria. PLoS One 9:e112271. doi:10.1371/journal.pone. 0112271

Pfaffl MW, Tichopad A, Prgomet C, Neuvians TP (2004) Determination of stable housekeeping genes, differentially regulated target genes and sample integrity: bestKeeper-excel-based tool using pair-wise correlations. Biotechnol Lett 26:509-515

Piepenbring M, Stoll M, Oberwinkler F (2002) The generic position of Ustilago maydis, Ustilago scitaminea, and Ustilago esculenta (Ustilaginales). Mycol Prog 1:71-80

Que Y, Su Y, Guo J, Wu Q, Xu L (2014) A global view of transcriptome dynamics during Sporisorium scitamineum challenge in sugarcane by RNA-seq. PLoS One 9(8):e106476. doi:10.1371/journal.pone.0106476

Ramakers C, Ruijter JM, Deprez RHL, Moorman AF (2003) Assumption-free analysis of quantitative real-time polymerase chain reaction (PCR) data. Neurosci Lett 339:62-66

Rocha FR, Papini-Terzi FS, Nishiyama MY et al (2007) Signal transduction-related responses to phytohormones and environmental challenges in sugarcane. BMC Genom 8:71

Sánchez-Elordi E, Baluška F, Echevarría C, Vicentea C, Legaz ME (2016) Defence sugarcane glycoproteins desorganize microtubules and prevent nuclear polarization and germination of Sporisorium scitamineum teliospores. J Plant Physiol. doi:10. 1016/j.jplph.2016.05.022

Santiago R, Alarcón B, de Armas R et al (2012) Changes in cinnamyl alcohol dehydrogenase activities from sugarcane cultivars inoculated with Sporisorium scitamineum sporidia. Physiol Plant 145:245-259

Schaker PDC, Palhares AC, Taniguti LM, Peters LP, Creste S, Aitken $\mathrm{KS}$ et al (2016) RNAseq transcriptional profiling following whip development in sugarcane smut disease. PLoS One 11(9):e0162237. doi:10.1371/journal.pone.0162237

Sevilla F, Camejo D, Ortiz-Espín A et al (2015) The thioredoxin/ peroxiredoxin/sulfiredoxin system: current overview on its redox function in plants and regulation by reactive oxygen and nitrogen species. J Exp Bot 66:2945-2955

Shetty NP, Mehrabi R, Lütken H et al (2007) Role of hydrogen peroxide during the interaction between the hemibiotrophic fungal pathogen Septoria tritici and wheat. New Phytol 174:637-647

Song X, Xing Huang B, Dandan Tian B et al (2013) Proteomic analysis of sugarcane seedling in response to Ustilago scitaminea Infection. Life Sci J 10:3026-3035

Su Y, Guo J, Ling H et al (2014) Isolation of a novel peroxisomal catalase gene from sugarcane, which is responsive to biotic and abiotic stresses. PLoS One 9:e84426. doi:10.1371/journal.pone. 0084426

Su Y, Wang Z, Xu L, Peng Q, Liu F, Li Z, Que Y (2016) Early selection for smut resistance in sugarcane using pathogen proliferation and changes in physiological and biochemical indices. Front Plant Sci 7:1133. doi:10.3389/fpls.2016.01133

Sundar AR, Barnabas EL, Malathi P, Viswanathan R (2012) A minireview on smut disease of sugarcane caused by Sporisorium scitamineum. In: Mworia JK (ed) Botany. InTech Rijeka, Croatia, pp 107-128

Tada Y, Spoel SH, Pajerowska-Mukhtar K et al (2008) Plant immunity requires conformational changes of NPR1 via S-nitrosylation and thioredoxins. Science 321:952-956

Taniguti LM, Schaker PDC, Benevenuto J et al (2015) Complete genome sequence of Sporisorium scitamineum and biotrophic interaction transcriptome with sugarcane. PLoS One 10:e0129318. doi:10.1371/journal.pone.0129318

Torres MA (2010) ROS in biotic interactions. Physiol Plant 138:414-429

Torres MA, Morales J, Sánchez-Rodríguez C et al (2013) Functional interplay between Arabidopsis NADPH oxidases and heterotrimeric G protein. Mol Plant Microbe Interact 26(6):686-694

Tuite J (1969) Plant pathological methods: fungi and bacteria, 1st edn. Burgess Publishing Company, Minneapolis 